\title{
Intra- and extra-bank determinants of Latin American Banks' profitability
}

\author{
Paolo Saona \\ Saint Louis University, John Cook School of Business, Av. Del Valle 34, 28003 Madrid, Spain
}

\section{A R T I C L E I N F O}

\section{Article history:}

Received 17 March 2015

Received in revised form 21 April 2016

Accepted 19 June 2016

Available online 22 June 2016

\section{JEL classification:}

C23

G21

L2

Keywords:

Bank profitability

Capital ratio

Diversification

Institutional environment

\begin{abstract}
A B S T R A C T
Using data on commercial banks in seven Latin American countries from 1995 to 2012, we find evidence of several major relationships involving bank profitability, including: 1) an inverse U-shaped relationship between banks' capital ratios and profitability, 2) a positive relationship between asset diversification (e.g. security trading, hedge funds, foreign exchange, assurance, etc.) and profitability, 3) a negative relationship between revenue diversification (e.g. interests, fees, commissions, etc.) and profitability, 4) a positive relationship between market concentration and profitability, and 5) improvements in the legal and regulatory system are associated with a negative impact on banks' profitability. This paper contributes to the literature by assessing these relationships using data on Latin American banks and by estimating their models using a system GMM approach that addresses issues arising from endogenous independent variables and heterogeneity among individual banks.
\end{abstract}

(c) 2016 Elsevier Inc. All rights reserved.

\section{Introduction}

Over the last thirty years, Latin American banking systems have experienced a rapid and deep structural transformation. This evolution has been characterized by the desire of governments to improve efficiency through deregulation of the banking system, several periods of privatization of financial institutions, and increasingly active participation of foreign banks. Additionally, during this process of consolidation, the economies in Latin America have experienced deeper regional integration as well as financial innovation.

Notwithstanding that all of these transformations have improved the allocation of financial resources, their economic impacts have not necessarily been positive. More complex risks, such as foreign exchange rate risk, interest rate risk, and general market risk, among others, as well as the inherent risk of new financial products, lower levels of diversification, and the introduction of new market regulations might have made these economies more vulnerable to internal and external shocks. These factors in conjunction with the consolidation of the banking sector in the region (largely driven by mergers, acquisitions and takeovers of local banks by foreign institutions), have impacted the way banks earn profits (Chortareas, Garza-Garcia, \& Girardone, 2011).

The profitability of banks is not just determined by the factors mentioned above but also and substantially by the different crises observed in the region during the last decades (e.g. Mexico, Venezuela, and Chile in mid-1990s, Argentina in 2001, Uruguay in 2007, among many others). According to Singh et al. (2005), despite the relatively high interest-rate spreads, profitability of credit agencies is still poor due to high operating costs and relatively high loan risks in the region's banking systems.

E-mail address: psaonaho@slu.edu. 
Initial research on bank performance focused on the determinants of interest margins. The seminal paper by Ho and Saunders (1981) served as the theoretical framework for most further research on the drivers of bank net interest margins. The dealership model of Ho and Saunders indicates that the optimal net interest margin is a function of risk aversion, the size of the bank, the degree of interest-rate risk on deposits and loans, and the degree of market competition. This model has been widely used, extended and improved on in the literature. ${ }^{1}$

Similar to Ben Naceur and Omran (2011), in this paper we follow an alternative approach focused on performance analysis using net interest margins with a more eclectic one-step estimation process based on a behavioral model of the banking firm. Previous literature on the study of bank profitability also considers this pragmatic approach of analysis where the determinants of profitability are classified by internal and external factors (Bourke, 1989; Demirgüç-Kunt \& Huizinga, 1999; Goddard, Molyneux, \& Wilson, 2004; Molyneux \& Thornton, 1992; Saona, 2011; Short, 1979). ${ }^{2}$ The literature usually considers that the internal drivers of bank profitability are those factors controllable by management which account for intra-firm differences in commercial bank profitability, given the external environment. The external factors comprise the entire set of those that are taken for granted, that are outside of the bank's control, and are expected to affect positively and/or negatively the bank's business (Athanasoglou, Brissimis, \& Delis, 2008; Olson \& Zoubi, 2011; Ramlall, 2009; Sufian \& Habibullah, 2009). These variables are basically determined by the legal and institutional framework, the financial system, and the peculiarities of the economic (macroeconomic) setting where the bank performs its operations (Demirgüç-Kunt, Laeven, \& Levine, 2004). Athanasoglou et al. (2008) investigate the determinants of bank profitability in a single equation framework broken down into three determinants of profitability: bank-specific (which involves operating efficiency, financial risk, and the bank's size), industry-specific (which includes variables that are not the direct result of managerial decisions) and macroeconomic-specific (cyclical output and expected inflation, for instance).

In this paper, we consider the second and third group of determinants together as part of our extra-bank drivers of bank profitability (Athanasoglou et al., 2008). The general goal of this paper is to determine the effect of intra- and extra-bank drivers of profitability of banks in Argentina, Brazil, Chile, Mexico, Paraguay, Peru and Venezuela for the period of 1995 to 2012.

Concerning the internal determinants of bank performance, in terms of functional diversification, the results show that asset diversification has contributed to improved performance of the banking sector in Latin America contrary to earlier findings on revenue diversification. The results also prove that market power, driven by a highly concentrated industry, impacts positively the net interest margin of the banks. Additionally, the capital ratio shows a non-linear relation with the banks' performance. This relationship is positive for low levels of capitalization, but shows that, after a certain critical point when capitalization continues growing, bank profitability worsens. Finally, we observe that the evolution of macroeconomic conditions, a crisis in the banking sector, the development of financial markets and the regulation of financial intermediation also impact the performance of banks in the region.

This work contributes to existing literature in a variety of different ways. First, the Latin American market provides a very interesting context to be studied due to the significant liberalization of its economies during times of regional economic crises, on the one hand, and the internationalization of its banking systems, on the other hand. ${ }^{3}$ This research aims to increase the empirical findings for Latin American banks by developing a comprehensive model of bank profitability. Most of the limitations of the current literature on Latin America are rooted in either the scope and/or the scale of their analyses. For instance, although they use samples for several countries, they study the banking profitability using bank-specific data only (Brock \& Rojas Suárez, 2000) or their samples of firms suffer from lack of representativeness in order to carry out further extrapolation (Gelos, 2009). Additionally, most of this already rather scarce empirical literature is focused on the analysis of individual countries such as Colombia (Barajas, Steiner, \& Salazar, 1999), Chile (Brock \& Franken, 2003), Argentina (Catão, 1998), or Brazil (Afanasieff, Lhacer, \& Kanane, 2002). Consequently, our study contributes to the literature by analyzing bank profitability through a more comprehensive model which includes the intra- and the extra-bank determinants.

Second, this paper improves upon the previous empirical literature on the analysis of bank performance by properly addressing problems of endogeneity and issues related to individual heterogeneity. We use the system estimator with GMM in our econometric analysis in order to deal with these problems.

The rest of this paper is structured as follows. Section 2 provides a description of the related literature and the research hypotheses. Section 3 develops the methodology applied in the empirical analysis and describes the variables used. The main results are shown in Section 4 and major conclusions are drawn in the final section.

\footnotetext{
${ }^{1}$ For instance, Lerner (1981) discusses critically that certain assumptions behind the model might lead to errors. Afterwards, Allen (1988) extends the Ho and Saunders model to consider the case of loan heterogeneity. In the context of European banks, Carbó Valverde and Rodríguez Fernández (2007) use a multi-output framework to show that the relationship between bank margins and market power varies significantly across bank specializations. Focused on the European Union banks, Maudos and Fernández de Guevara (2004) widen the Ho and Saunders model to take banks' operating costs explicitly into account. Additionally, Saunders and Schumacher (2000) use a multicountry setting and decompose bank margins into a regulatory component, a market structure component and a risk premium component.

2 They also break down this classification into both financial and non-financial (off-balance sheet) statement variables.

${ }^{3}$ An example of this is the consolidation of the Latin American banking system driven basically by the acquisition of local banks by foreign institutions (Yeyati \& Micco, 2007). The liberalization of the banking systems around the world has being characterized by the abolition of interest rate controls and of barriers to the entry of foreign banks, new domestic banks and non-bank financial intermediaries, and a reduction in state ownership and in politically directed loans, often at concessionary rates, to specific sectors (Feldmann, 2012).
} 


\section{Related literature and research hypotheses}

\subsection{Measures of performance}

Following Demirgüç-Kunt and Huizinga (1999) we use as a measure of bank performance the bank interest spread or net interest margin. We use ex-post spreads which are computed as the difference between the banks' actual interest revenues and their actual interest expenses. This ex-post spread differs from the ex-ante spread by the amount of loan defaults. The ex-post spread is a more useful measure because it controls for the fact that banks with high-yield, risky credits are likely to face more defaults.

For robustness checks of our results, we use other three alternative measures of the net interest margin also based on the ex-post spreads as seen in Section $4.4 .^{4}$

\subsection{Drivers of banks' performance and their associated hypotheses}

This section provides a detailed description of the most important drivers of bank performance and the hypotheses derived from these drivers. Unlike the relatively scarce literature focused on Latin America, the major purpose of this paper is to include a comprehensive set of determinants of bank performance classified into two big categories: intra-bank determinants and extra-bank determinants. The first group includes all the variables which are management controlled or bank-based. The second group, however, corresponds to those variables taken for granted by financial institutions which cannot be modified (or substantially modified) through managerial decisions. Therefore, all the economic and industry specific variables are included in this group.

\subsubsection{Intra-bank determinants}

These variables correspond to those determined by the bank's managerial decisions. The literature recognizes a number of variables in this respect, but their inclusion has not always been properly justified in cross-sectional analysis. In this respect we have entered into the models the following variables.

i) capital ratio. Although this variable is partially determined by regulatory capital (e.g. Basel I and Basel III, for instance), the purpose of the capital ratio is to compute a reciprocal measure of leverage. The regulatory capital, however, corresponds to the minimum required capital to cover risk-weighted assets (e.g. subordinated debt, non-deferrable assets, and hybrid instruments, among other risky assets which unfortunately we are unable to determine). Nevertheless, for this period of analysis, the countries in our sample hold consistently greater levels of capital than those required by legislation for the risk-adjusted regulatory capital. ${ }^{5}$ Additionally, due to the previously mentioned scarce literature on Latin America, we consider this variable to be a bank-based determinant (Chortareas et al., 2011; Gelos, 2009) although we recognize it might be partially determined by the regulatory system.

ii) functional diversification. This has not been studied in the Latin American context and is a product of managers' decisions to reduce risk and explore new business opportunities.

iii) bank size, which incorporates the capacity of managers to invest in different assets.

iv) credit risk, which records the level of risk at which banks' managers are managing the investment portfolios.

v) bank concentration. This variable is mostly considered in the literature as a country-based variable. However, for the Latin American context this variable will be considered an intra-bank determinant because as a consequence of the liberalization and deregulation of the markets, banks have been involved in mergers and acquisitions as part of their growth strategies.

vi) bank loans.

vii) bank deposits.

These last two variables by their very nature are determined by managerial decisions as part of operating activities.

2.2.1.1. Capital ratio. There are arguments which support a positive as well a negative impact of the capital ratio on the bank's profitability. Berger (1995b) argues that a positive relationship is supported by two complementary arguments. First, the expected bankruptcy costs hypothesis suggests that banks will increase their capital whenever exogenous factors increasing the expected bankruptcy costs are greater. Second, the signaling hypothesis suggests that management might be willing to convey information to the market about its future prospects and capacity to generate profits. As a result, a signaling equilibrium might exist where banks expecting to have improved future performance will exhibit higher capital ratios.

Additionally, a higher capital ratio involves a higher flexibility to take advantage of new business opportunities (Goddard et al., 2004), mostly when banks have financial constraints such as in the context of emerging markets.

Besides these arguments, the literature also supports a negative relationship between capital and banks' performance. An excessively high capital ratio might denote that a bank is operating over-cautiously and ignoring potential profitable growth

\footnotetext{
4 Preliminary results were also computed with the return on assets $(R O A)$ as dependent variable. This variable measures the profit earned per monetary unit and reflects how well bank management uses the bank's real investment resources to generate profits (Ben Naceur \& Goaied, 2008). Results with ROA variable were not finally tabulated in this work for their lack of consistency and robustness. Moreover, we believe that the NIM is a more suitable measure of banks performance than ROA because the NIM measures the profit earned on typical banking activities such as lending, investing and funding activities; whilst the ROA, in addition to that, includes the profits and losses generated and spent by non-operating activities and the taxes which might bias the measure of bank profitability.

${ }^{5}$ About $8 \%$ which might vary among countries (Warman, 2013).
} 
options (Berger, 1995a; Saona, 2011), implying higher opportunity costs of capital. In the same vein, according to the agency costs hypothesis (Jensen, 1986; Jensen \& Meckling, 1976), high leverage - or, in other words, a low capital ratio - reduces the agency costs of outside equity and increases firm value by constraining or encouraging managers to act more in the interest of shareholders, which eventually leads toward better performance. However, when the capital ratio increases substantially, banks do not take advantage of debt for financing future growth options and the firm value is eroded. These arguments suggest an optimal level of equity capital.

Unlike the evolution of other banking industries such as those in the US or EU, the banking sector in Latin America has experienced profound changes due to deregulation, foreign investment, and restructuring after periods of financial crises over the last three decades. Such consolidation has come together with the instability embedded in a higher credit risk than that which has occurred in other regions (Chortareas et al., 2011). Consequently, the amount of capital used by financial institutions in this context might become even more important than in industrialized countries. Thus, reinforcing the arguments developed above, the particular characteristics of the banking sector in Latin America suggest that banks will follow an optimal level of capital which allows them to operate efficiently in economically and financially unstable environments.

Most of the previous empirical literature uses a monotonic linear relationship between the capital ratio and profitability (Ben Naceur \& Omran, 2011; Chaudhry, Chatrath, \& Kamath, 1995; Goddard et al., 2004; Molyneux, Remolona, \& Seth, 1998; Molyneux \& Thornton, 1992). However, the theoretical arguments as well as the characteristics of the institutional environment in Latin America allow hypothesizing a non-monotonic relationship between the capital ratio and bank performance.

2.2.1.2. Functional diversification. The empirical literature provides mixed results for the relationship between functional diversification and bank performance in developed countries. For instance, Mercieca, Schaeck, and Wolfe (2007), Wall and Eisenbeis (1984), DeYoung and Roland (2001), Berger, Hasan, and Zhou (2010), Demirgüç-Kunt et al. (2004), among others, find that banks do not benefit from diversification. Nevertheless, Cybo-Ottone and Murgia (2000) and Lepetit, Nys, Rous, and Tarazi (2008) find significant positive abnormal returns associated with product diversification of banks.

However, in the more recent Latin American context, fee-based and financial advisory services constitute an additional source of revenues. After the process of liberalization and international integration in Latin America with banks mainly from Western Europe and the US, the traditional banking business of the 1980s has gradually pursued functional diversification through activities such as electronic pursue, delivery channels, clearing systems, investment banking, security trading, hedge funds, foreign exchange, insurance, and other financial services able to generate revenue in a variety of different ways, including interest, fees, and commissions (Valdez, 2007). Such a dramatic change in the role of the banking sector in the last decades, moving from traditional operations toward more sophisticated transactions, supports the hypothesis of a positive impact on bank performance caused by higher functional diversification.

2.2.1.3. Bank size. Athanasoglou et al. (2008) suggest that in general the effect of a growing size on profitability has proven to be positive to a certain extent. In this respect, Goddard et al. (2004) supported their arguments on economies of scale and showed that, at small asset sizes, banks can take advantage of economies of scale, but they become exhausted as the size of their assets increases.

The empirical literature finds, for instance, that Mexican banks with larger operations bear higher risk and, thus, charge higher margins, improving their performance (Maudos \& Solís, 2009). Similarly, Chortareas et al. (2011) find that if banks are operating in the increasing returns portion of their average cost curve, then bank profits are positively affected. These arguments seem to fit with the reality of the banking systems in Latin America. After long periods of internationalization of their financial systems, mergers and acquisitions basically by foreign banks have dominated the evolution of the banking system in the region. Such processes have been demonstrated in a large concentration of banks and are further evidenced in the dramatic increase of the size of the banks (Chortareas et al., 2011). Consequently, it is expected that bank size will positively impact profitability if banks are operating at increasing returns of scale.

2.2.1.4. Creditrisk. It has been suggested that increased exposure to credit risk is usually associated with decreased firm profitability (Athanasoglou et al., 2008). Therefore, the way banks can improve their performance is by means of screening and monitoring their credit risk. For instance, Miller and Noulas (1997) find that the more financial institutions are exposed to high-risk loans, the higher the accumulation of unpaid loans and the lower the profitability in the US banking system. Although such typically negative correlations between credit risk and net interest margin have been observed in developed countries, we should expect the opposite situation in emerging economies such as in Latin America. This argument is supported by the idea that banks with more risky loans will require a higher net interest margin to compensate for their greater risk of default (Figlewski, Frydman, \& Liang, 2012; Lin, Chung, Hsieh, \& Wu, 2012). Similarly, de Blas and Russ (2013) as well as Gelos (2009) suggest that since macroeconomic volatility in emerging markets is much higher than in developed countries, this may raise the risk of default and consequently it is plausible that bank spreads may increase. Consequently, we hypothesize a positive impact of the credit risk on the bank's net interest margins in Latin America.

2.2.1.5. Bank concentration. According to both the market power and the efficient-structure hypotheses, there is a positive relationship between bank concentration and performance (Almeida \& Divino, 2015; Saona, 2011). Bourke (1989) and Molyneux and Thornton (1992) state that this positive correlation is due to increased market power that yields monopolistic profits due to deviations from competitive markets. The collusion hypothesis also supports a positive relationship between bank 
concentration and performance. Subsequently, highly concentrated markets will lower the cost of collusion and foster tacit and/ or explicit collusion between firms. However, if the number of banks operating is large, the cost of collusion increases because it is more difficult to carry out (Goddard et al., 2004). Nevertheless, if collusion is feasible, banks will be able to earn monopoly rents.

The presence of foreign banks has increased substantially in Latin America since the 1990s with European and US banks being the main investors through mergers and acquisitions in the entire region (Yeyati \& Micco, 2007). As a consequence of weak law enforcement in Latin America, collusion activities along with other anticompetitive practices have generated abnormal bank profits and ultimately burdened consumers through higher than competitive loan interest rates, credit rationing, and the downgrading of banking services (Chortareas et al., 2011). Consequently, a positive relationship is expected between banking concentration and profits.

2.2.1.6. Bank loans. These are expected to be the main source of income and to have a positive impact on bank performance (Ben Naceur \& Goaied, 2008). Assuming no change in other factors, if more deposits are converted into loans, then the observance of higher interest margins and profits would be expected. Empirical studies find that higher loan ratios are associated with higher interest margins, suggesting that risk-averse shareholders seek higher earnings to compensate for higher credit risk (Ben Naceur \& Goaied, 2008; Maudos \& Fernández de Guevara, 2004). Nevertheless, Demirgüç-Kunt and Huizinga (1999) find that there is a negative correlation between bank loans and earnings before taxes, but when the bank loans interact with GDP it becomes positive. This fact indicates that at higher income levels a bank's lending activities tend to be more profitable. In a recent paper, Ben Naceur and Omran (2011) find that when market conditions enable the bank to provide additional loans with a profitable return/risk profile, this will improve the interest margin. Therefore, the expected empirical relationship between bank loans and profitability should be positive.

2.2.1.7. Bank deposits. The demand for deposits represents profit opportunities (Berger, 1995a, 1995b; Berger \& Bonaccorsi di Patti, 2006; Goddard et al., 2004). The demand for deposits is a primary source of agency problems due to insurance protections given by the government (Berger, 1995a). In this case, one can expect a negative relationship between this variable and bank's profitability. Nevertheless, the lack of competitive credit conditions in Latin America and the limited access to international capital markets lead banks to finance their growth with lower proportions of wholesale markets and higher proportions of customer deposits. Following the arguments of Trujillo-Ponce (2013), under this scenario, the deposits constitute a cheap and stable financial resource versus other financing alternatives, which supports a positive relationship between the banks' performance and customer deposits for the Latin American context.

\subsubsection{Extra-bank determinants}

The empirical literature has been quite prolific also in providing drivers of performance for banks which are determined exogenously. This set of variables is named here as extra-bank determinants since they correspond to all those variables that are not defined internally by managerial decisions, but by the current economic conditions, institutional systems, and regulatory framework. Demirgüç-Kunt et al. (2004) is one of the first papers focused on the examination of the impact of these external determinants on bank interest margins. They find that bank-specific variables as well as banking regulations seem to explain a substantial part of the within-country variation in banks' performance. Moreover, the authors stress the fact that bank regulations cannot be viewed in isolation from the overall institutional framework. Consequently, we consider financial development and legal enforcement and regulatory systems to fall within the extra-bank determinants of net interest margin.

2.2.2.1. Financial development. The level of financial development across countries is also a widely mentioned driver of banks' performance. Demirgüç-Kunt and Huizinga (1999) suggest a negative relationship between the size of the developed banking sectors and profitability that reflects the higher level of competition. Later on, Demirgüç-Kunt and Levine (2004) find that financial development has a significant impact on bank profitability, pointing out that countries with developed stock markets might create a competitive environment that puts downward pressure on bank interest margins. Similarly, Ben Naceur and Omran (2011) suggest that a developed banking system reduces profitability through increased competitiveness, whereas stock market development improves bank performance especially in a lower stages of financial development. Consequently, it is expected that the process of financial liberalization and integration in Latin American will reduce the bank spreads.

2.2.2.2. Legal enforcement and regulatory system. Demirgüç-Kunt and Huizinga (1999) and later on Demirgüç-Kunt et al. (2004) find that better legal enforcement and more efficient regulatory systems are associated with lower levels of corruption, both of which allow the financial system to perform with fewer frictions. Therefore, they suggest that there is a negative association between legal enforcement and the efficiency of the regulatory system and profitability of banks. Ben Naceur and Omran (2011), however, find that an improvement in law and order decreases the cost of efficiency without affecting performance. Gelos (2009) argues that a high recovery rate and shorter times to repossess collateral in countries with better legal environments are expected to reduce bank spreads. Therefore, due to the particular characteristics of lower enforcement in legal system in Latin American economies we should expect that this variable negatively impacts the performance of banks.

Finally, we consider as control variables the inflation rate (Perry, 1992), the growth rate of GDP per capita (Ben Naceur \& Goaied, 2008), the reserve requirements (Brock \& Rojas Suárez, 2000; Demirgüç-Kunt et al., 2004), and the economic crises (De la Torre, Ize, \& Schmukler, 2012). 
Table 1

Panel structure.

The table describes the composition of the panel data used in the empirical analysis.

\begin{tabular}{|c|c|c|c|c|c|}
\hline \multirow[b]{2}{*}{ Country } & \multicolumn{2}{|l|}{ Obs. } & \multicolumn{2}{|l|}{ Firms } & \multirow[b]{2}{*}{ Average obs. per firm } \\
\hline & Number & $\%$ & Number & $\%$ & \\
\hline Argentina & 76 & $7.88 \%$ & 13 & $8.33 \%$ & 5.85 \\
\hline Brazil & 228 & $23.65 \%$ & 38 & $24.36 \%$ & 6.00 \\
\hline Chile & 71 & $7.37 \%$ & 13 & $8.33 \%$ & 5.46 \\
\hline Mexico & 184 & $19.09 \%$ & 31 & $19.87 \%$ & 5.94 \\
\hline Paraguay & 252 & $26.14 \%$ & 35 & $22.44 \%$ & 7.20 \\
\hline Peru & 63 & $6.54 \%$ & 10 & $6.41 \%$ & 6.30 \\
\hline Venezuela & 90 & $9.34 \%$ & 16 & $10.26 \%$ & 5.63 \\
\hline Total & 964 & $100.00 \%$ & 156 & $100.00 \%$ & 6.18 \\
\hline
\end{tabular}

\section{Methodology and variables' measurement}

\subsection{Methodology}

The statistical analysis is conducted with a sample of 156 banks from Argentina, Brazil, Chile, Mexico, Paraguay, Peru, and Venezuela. The composition of the panel data is described in Table 1. In order to compound an efficient panel data, we included a minimum of 5 with an average of 6.18 continuous year observations per bank. The panel data include 964 observations over the years 1995 to 2012. We intended to collect as much data as possible in order to include at least the Asian crisis of 1997 and the subprime crisis of 2007-8 to study their impact on the performance of banks. Banks included in the sample had to fulfill the following criteria during the period of analysis: first, to have at least five consecutive years of full reporting; second, no trading restrictions by their local stock exchange commissions nor could they have filed for bankruptcy; third, merged banks were also removed from the sample as well as banks with evident outlier variables and those with negative equity capital. Although we account only with a few banks observed cross the entire period of analysis, the observations per year are quite balanced along the entire period with only a slightly higher concentration of the observations on the more recent years as consequence of the improvements in the financial reporting systems. ${ }^{6}$ According to Baltagi (2013), panel data allows us to deal efficiently with this issue since the panel has a higher informative content than cross sectional analysis, it provides higher variability, lower collinearity among explicative variables, more degrees of freedom and higher efficiency.

The microeconomic annual data at bank-level (financial statements) was gathered from the Economatica Dataset. The macroeconomic information at country level was obtained from the updated data of Beck, Demirgüç-Kunt, and Levine (2000) publicly available at the World Bank web page. ${ }^{7}$ The panel data is unbalanced and includes all the active banks for which we had complete information for the econometric analysis. The sample is representative of the Latin American banking system because it includes the largest financial institutions per country based on their market capitalization, representing a significant proportion of the assets of the banking system in the region.

Due to the panel structure of our data, which is a combination of cross sectional and time series information, we have estimated our model using the generalized method of moments (GMM). The panel data methodology allows us to control for two basic problems in this kind of studies: unobservable heterogeneity and the endogeneity problems (Arellano, 2002).

Constant and unobservable heterogeneity refers to specific characteristics of each bank that remain constant over time (e.g. managerial style, attitude toward risk, internal policies, among others). Since they are unobservable, they become part of the random component in the estimated model. The endogeneity problem might appear when the capital ratio is affected by bank performance (Goddard et al., 2004; Saona, 2011; Trujillo-Ponce, 2013). This problem is exacerbated in our model because the lagged dependent variable is also included as an explanatory variable. To address this problem, we estimate our model using Blundell and Bond (1998)'s and Bond (2002)'s panel data system estimator.

Because in both of these problems the independent variables are endogenous and correlated with residuals of the regressions, the OLS estimation is both biased and inconsistent (Brown, Beekes, \& Verhoeven, 2011). As a result, we address the endogeneity and unobservable heterogeneity problems in the estimations by using the GMM estimator proposed by Blundell and Bond (1998) and Bond (2002) which might provide further efficiency gains. Due to the possible weakness of the instruments stated by Alonso-Borrego and Arellano (1999), the GMM system estimator returns the most efficient and consistent estimations. In this context, the choice of instruments is a key decision in handling the endogeneity problem. According to Athanasoglou et al. (2008), the capital ratio is better modeled as an endogenous determinant of bank profitability in econometric models. We use as instruments the capital ratio up to three years lagged. Following Almeida and Divino (2015), the Hansen, Heaton, and Yaron (1996) test of overidentified restrictions is used to check if the instruments are exogenous. The AR(1) and AR(2) statistics measure the first- and second-order serial correlation, respectively. Regarding the serial correlation, it is expected that the null hypothesis of no first-order autocorrelation is not rejected. However, this is not considered a problem because $\Delta \varepsilon_{i t}=\varepsilon_{i t}-\varepsilon_{i t-1}$ might be correlated with $\Delta \varepsilon_{i t-1}=\varepsilon_{i t-1}-\varepsilon_{i t-2}$ given

\footnotetext{
${ }^{6}$ Estimations for the sub-sample periods of 1995-2007 and 2000-2012 were conducted to test consistency and significance of the results. These estimations were found robust in both periods of time. These results are not tabulated but available upon request to the author.

7 The latest update took place in November 2013. Information can be downloaded from the permanent URL http://go.worldbank.org/X23UD9QUX0.
} 
that both share the common term $\varepsilon_{i t-1}$. Therefore, one must also perform the test for second-order autocorrelation, AR(2). No rejection of the null hypothesis indicates that the moment conditions are valid. The Lind and Mehlum (2010) contrast is applied in order to test the existence of a non-linear relationship between bank's capitalization and profitability. The Wald test of joint significance is also used to assess the significance of all the independent variables in the sample.

We use micropanel data in which the cross-section dimension far exceeds the time-series dimension (i.e. we have many more firms than years). In this type of model, the temporal and cross-sectional independence of the variables is not a relevant issue because the time effect and the individual effect are explicitly taken into account in the model. Consequently, according to Jara, López, and López-de-Foronda (2008) the variables do not need to be transformed to stationary before estimating the model. Nevertheless, we used a Fisher-type (Choi, 2001) test which has as null hypothesis that all the panels contain a unit root to test the stationarity of the variables in the model. ${ }^{8}$ The Fisher-type test for panel data unit roots follows a meta-analysis perspective. That is, this test conducts unit-root tests for each panel individually, and then combines their p-values to produce an overall test.

According to Berger and Bonaccorsi di Patti (2006) bank profits show a tendency to persist over time. This persistence can be the result of the market competition barriers, banks' regulatory capital-ratios enforcement, informational opacity and/or sensitivity to external shocks, to the extent that there is a serial correlation between them (Buser, Chen, \& Kane, 1981; Memmel \& Raupach, 2010). Then, these arguments suggest the application of a dynamic model of banking profitability which takes the following form:

$$
N I M_{i t}=\beta_{0}+\beta_{1} N I M_{i t-1}+\sum_{j=1}^{8} \delta_{j} X_{i t}+\sum_{k=1}^{2} \theta_{k} Y_{t}+\eta_{i}+\mu_{t}+\varepsilon_{i t}
$$

Where $X_{i t}$ represents the vector of the intra-bank determinants of profitability, $Y_{t}$ is the vector of the extra-bank determinants and $\eta_{i}, \mu_{\mathrm{t}}$ and $\varepsilon_{i t}$ measure the individual effect, the temporal effect, and the stochastic error, respectively. Specifically,

$$
\sum_{j=1}^{8} \delta_{j} X_{i t}=\delta_{1} C A P_{i t}+\delta_{2} \text { CAP }_{i t}^{2}+\delta_{3} \text { DIVERSIF }_{i t}+\delta_{4} \text { SIZE }_{i t}+\delta_{5} \text { CREDITRISK }_{i t}+\delta_{6} \text { CONC }_{i t}+\delta_{7} \text { LOAN }_{i t}+\delta_{8} \text { DEPTA }_{i t}
$$

and

$$
\sum_{k=1}^{2} \theta_{k} Y_{t}=\theta_{1} \text { FINDEV }_{i t}+\theta_{2} L A W_{i t}
$$

The definitions of all the dependent, independent and control variables are provided in the following section.

\subsection{Variables definition}

Profitability as the dependent variable is measured by the net interest margin (NIM1) calculated as net interest revenue over average earning assets. The net interest revenue is an ex-post measure of the bank's spreads which corresponds to the difference between the banks actual interest revenues and their actual interest expenses. Alternatively, we use three measures of net interest margin calculated as the net interest revenue over average total assets (NIM2); net interest revenue over total assets (NIM3); and the net interest revenue over total earning assets (NIM4).

Concerning the intra-bank determinants, we measured bank capital ratio (CAP) as the book value of equity capital divided by total assets (Angbazo, 1997; Ben Naceur \& Goaied, 2008; Saona, 2011). Following Demirgüç-Kunt and Huizinga (1999) we use as an alternative variable of bank capital ratio the book value of equity capital divided by total assets lagged one period. The reason for using a one-period lag for this variable is to correct for the fact that profits, if not paid out as dividends, have a contemporaneous impact on bank equity (Demirgüç-Kunt \& Huizinga, 1999). ${ }^{9}$ In order to test the non-linear relationship between bank performance and their capital ratio, we use the quadratic term for capital ratio $(C A P)^{2}$.

In order to measure bank functional diversification (DIVERSIF) we follow a pragmatic definition of the degree of both assets and revenue diversification (Baele, De Jonghe, \& Vander Vennet, 2007; Laeven \& Levine, 2007; Lin et al., 2012). Asset diversity is based on stock variables, whilst revenue diversity is based on flow variables. Then, diversity is measured as DIVERSIF $=1-$ $|2 x-1|$, where $x$ is either the loan-to-asset ratio or the ratio of non-interest income to total operating income - the higher this ratio is, the more a bank relies on non-traditional banking activities. Diversity measured in this way takes values between 0 and 1 which means that the firm diversification increases with higher values for DIVERSIF. ${ }^{10}$

Bank size (SIZE) is measured as the natural logarithm of total assets (Ben Naceur \& Omran, 2011; Demirgüç-Kunt et al., 2004). The credit risk (CREDRISK1) is measured by the loan loss provision over total loans (Lin et al., 2012). As an additional measure of risk, the ratio of net loans to total loans (CREDRISK2) is used (Ben Naceur \& Omran, 2011).

Following Ben Naceur and Goaied (2008) we measure bank concentration (CONC1) as the fraction of bank assets held by the three largest commercial banks in each country. As an alternative measure for concentration we used the Lerner Index (CONC2), which has been widely used in the specific case of banks (Maudos \& Fernández de Guevara, 2004). This index corresponds to the

\footnotetext{
${ }^{8}$ We used the Fisher-type test because it does not require strongly balanced data.

9 Although the regression outputs with this alternative variable are not tabulated for space saving reasons, all the results were consistent with those shown in this work.

10 This measure for diversification relies on the assumption that an equal division between lending and non-lending activities constitutes the optimal diversification mix (Baele et al., 2007).
} 
negative inverse demand elasticity. The values of the index range from 0 (perfect competition) to 1 (monopoly) (Hawtrey \& Liang, 2008). Since CONC1 was significant only in a handful of regressions, we decided not to report the results for this variable.

The loan-to-asset ratio (LOAN) measures banks loans (Lin et al., 2012). This records the business capacity of a bank and corresponds to total gross loans and leases divided by total assets (Saona, 2011). The demand for deposits (DEPTA) is measured by the ratio of total deposits over total assets (Berger \& Bonaccorsi di Patti, 2006; Maudos \& Solís, 2009).

Concerning the extra-bank determinants we use the stock market capitalization over GDP as a proxy for financial development (FINDEV1) (Ben Naceur \& Goaied, 2008) and alternatively we used the quotient of the private credit by deposit money banks over GDP (FINDEV2) (Demirgüç-Kunt et al., 2004). The legal enforcement variable (LAW1) was taken from La Porta, Lopez-De-Silanes, and Shleifer (2006) and is a measure of the effective rights of minority shareholders. Its scale is from 1 to 10 . As an alternative variable of creditor rights and legal framework, we have used the Legal System and Property Rights index (LAW2) from the updated Economic Freedom Index of the World Annual Reports (Gelos, 2009). This index is comprised by a $0-10$ scale and is a composite index of economic freedom (the higher the index the higher the economic freedom). ${ }^{11}$

Among the control variables we included the annual inflation rate (INFL) (Demirgüç-Kunt \& Huizinga, 1999) and the GDP per capita growth rate (GDPGROWTH) which is also measured on an annual basis. Following Ben Naceur and Omran (2011) we proxy the reserve requirements (RESERVE) as the ratio of non-interest earnings assets divided by total assets. The impact of the economic crises (CRISIS) in the banking industry was measured as the insolvency risk for the whole industry by country (Beck et al., 2000). This variable is estimated as CRISIS $=\left(R O A+\frac{\text { Equity }}{\text { TotalAssets }}\right) / \sigma_{R O A}$; where $\sigma_{R O A}$ is the standard deviation of $R O A$ measured as the net income over total assets. Dummy variables by country and year were also entered into the model.

In addition to the extra-bank determinants already described here, we used an alternative set of variables similar to those used in Vallelado and Saona (2011), such as: growth rate of GDP (GDP); total bank deposits (BANKDEP) (defined as the demand, time and saving deposits in deposit-taking banks as a share of GDP); foreign banks (FOREIGNBANK); cost income ratio (CIR) (which is the total cost as a share of total income of all commercial banks); and the stock market turnover ratio (STOCKMKTO) (which is the value of total shares traded to average market capitalization). The source of this information was the updated dataset gathered by Beck et al. (2000). In addition to this, we included the corruption index (CORRUPT) obtained from Perception Index of Transparency and Corruption gathered by Transparency International. This index ranges between 0 (highly corrupt) and 10 (very clean).

In order to deal with the large number of extra-bank determinants and the high correlation among them, we use the principal component analysis. This type of analysis is a variable reduction procedure. It is useful because we have obtained data on a large number of variables, and believe that there is some redundancy in those variables. In this case, redundancy means that some of the variables are correlated with one another, possibly because they are measuring the same construct. Through this technique we can reduce the observed variables into a smaller number of principal components (factors) that account for most of the variance in the observed variables (Kim \& Mueller, 1978).

\section{Results}

\subsection{Descriptive statistics}

Table 2 provides an initial outline of the variables used in the regression analysis for the whole sample. The four different measures of the net interest margin (NIM1, NIM2, NIM3 and NIM4) are consistent with the average values recorded in previous literature for emerging markets (Fungáčová \& Poghosyan, 2011; Gelos, 2009; Lin et al., 2012) and substantially higher than in industrialized countries (Angbazo, 1997; Miller \& Noulas, 1997). The average of the net interest margin among these four variables is about $7.13 \%$.

Exhibit 1 describes a graphical evolution of the NIM1 as the main measure of banks' profitability. First of all, we can observe that the attempts at liberalization and deregulation experienced by Latin America during the 1990s helped to consolidate the financial systems across-countries. Although the financial sector still remains highly focused on banking and financial intermediation, this is low compared to other industrialized countries and such consolidation has decreased intermediation costs after the 1990s (see first graph). At least two periods of economic crises had consequences for the evolution of profitability in the Latin American banking industry: first the Asian crisis in 1997 and then the subprime crisis afterwards in 2007 and 2008. In the second graph, the profit margin for some countries has increased and for others it has decreased during the period of analysis. It can clearly be perceived that the bank freeze in Argentina in 2001 destabilized its financial system for several years. For Venezuela we observe that the lack of competitive markets allowed banks to set high spreads during the first years after the 1990s. A noteworthy exception is Chile, where bank interest margins displayed not only levels but also demonstrated a degree of stability comparable to that of developed countries. It seems to be that during the last years of our analysis, there is a discernible convergence process in the net interest margin among all the countries in the sample.

Table 2 also shows that the asset (revenue) diversification measured by DIVERSIF1 (DIVERSIF2) has an average coefficient of 0.704 (0.494). The diversification coefficient ranges from 0 to 1 and this value increases with the degree of diversification. $2.6 \%$ of total loans are loan loss provisions (CREDITRISK1). Table 2 also shows the description by country. We can see that Venezuela, Paraguay, and Brazil

\footnotetext{
11 Since we do not have updated information for the construction of $L A W 1$ which was taken from La Porta et al. (2006), we assumed that this proxy for the legal enforcement and regulatory system is invariant along the period of analysis. Nevertheless, in order to deal with this drawback in the measurement of this variable, we used also $L A W 2$ which varies along time and reported comparable results in the regression outputs. For saving space reasons, the results using $L A W 2$ are not reported, but they are available upon request to the authors.
} 
Table 2

Descriptive statistics by country.

This table reports the mean, standard deviation, minimum and maximum values of the variables used in the empirical analysis. This information is provided for the whole sample and by country. Basically these variables are classified as intra-bank and extra-bank determinants of the banks' profitability. Detailed information about the computation of each variable is provided in Section 3.2.

\begin{tabular}{|c|c|c|c|c|c|c|c|c|c|c|c|c|}
\hline Variables/countries & Obs. & Mean & Std. Dev. & Min. & Max. & Argentina & Brazil & Chile & Mexico & Paraguay & Peru & Venezuela \\
\hline \multicolumn{13}{|c|}{ Intra-bank determinants } \\
\hline NIM1 & 964 & 0.083 & 0.054 & -0.180 & 0.430 & 0.036 & 0.085 & 0.069 & 0.062 & 0.104 & 0.067 & 0.132 \\
\hline NIM2 & 964 & 0.065 & 0.040 & -0.120 & 0.327 & 0.029 & 0.071 & 0.059 & 0.051 & 0.072 & 0.058 & 0.096 \\
\hline NIM3 & 964 & 0.060 & 0.037 & -0.080 & 0.311 & 0.028 & 0.066 & 0.051 & 0.047 & 0.067 & 0.055 & 0.083 \\
\hline NIM4 & 964 & 0.077 & 0.051 & -0.159 & 0.431 & 0.035 & 0.079 & 0.058 & 0.058 & 0.097 & 0.064 & 0.112 \\
\hline CAP & 964 & 0.117 & 0.083 & 0.022 & 0.974 & 0.097 & 0.097 & 0.107 & 0.098 & 0.147 & 0.094 & 0.162 \\
\hline $\mathrm{CAP}^{2}$ & 964 & 0.021 & 0.060 & 0.000 & 0.949 & 0.010 & 0.012 & 0.015 & 0.014 & 0.030 & 0.009 & 0.067 \\
\hline DIVERSIF1 (asset) & 964 & 0.704 & 0.228 & 0.000 & 1.000 & 0.833 & 0.663 & 0.545 & 0.594 & 0.746 & 0.820 & 0.746 \\
\hline DIVERSIF2 (revenue) & 964 & 0.494 & 0.261 & 0.000 & 0.999 & 0.568 & 0.437 & 0.565 & 0.500 & 0.484 & 0.633 & 0.442 \\
\hline SIZE & 964 & 11.431 & 1.615 & 9.215 & 17.172 & 9.838 & 10.603 & 10.218 & 10.968 & 12.998 & 10.176 & 11.091 \\
\hline CREDRISK1 & 964 & 0.026 & 0.048 & -0.131 & 0.749 & 0.016 & 0.033 & 0.021 & 0.026 & 0.022 & 0.017 & 0.034 \\
\hline CREDRISK2 & 964 & 0.454 & 0.179 & 0.005 & 0.920 & 0.452 & 0.333 & 0.656 & 0.488 & 0.483 & 0.553 & 0.423 \\
\hline CONS1 & 964 & 50.003 & 14.313 & 27.512 & 87.210 & 37.058 & 39.452 & 53.345 & 66.496 & 45.463 & 71.743 & 48.041 \\
\hline CONS2 & 964 & 0.256 & 0.164 & 0.002 & 0.504 & 0.309 & 0.274 & 0.293 & 0.234 & 0.219 & 0.303 & 0.261 \\
\hline LOAN & 964 & 0.479 & 0.187 & 0.005 & 0.783 & 0.474 & 0.355 & 0.677 & 0.518 & 0.506 & 0.590 & 0.447 \\
\hline DEPTA & 964 & 0.607 & 0.211 & 0.000 & 0.852 & 0.581 & 0.374 & 0.687 & 0.613 & 0.682 & 0.796 & 0.749 \\
\hline \multicolumn{13}{|c|}{ Extra-bank determinants } \\
\hline INFL & 964 & 0.104 & 0.117 & -0.012 & 0.999 & 0.076 & 0.087 & 0.036 & 0.092 & 0.100 & 0.031 & 0.321 \\
\hline GDPGROWTH & 964 & 0.014 & 0.041 & -0.117 & 0.162 & 0.035 & 0.021 & 0.027 & 0.008 & 0.003 & 0.038 & 0.001 \\
\hline FINDEV1 & 955 & 26.681 & 14.625 & 0.489 & 59.544 & 30.191 & 44.102 & 105.320 & 27.939 & 3.090 & 41.591 & 6.556 \\
\hline FINDEV2 & 964 & 25.738 & 13.245 & 6.635 & 81.757 & 14.518 & 34.291 & 68.540 & 17.979 & 24.075 & 21.535 & 12.995 \\
\hline RESERVE1 & 964 & 0.189 & 0.125 & 0.006 & 0.812 & 0.150 & 0.148 & 0.143 & 0.167 & 0.274 & 0.109 & 0.228 \\
\hline LAW1 & 964 & 3.482 & 1.252 & 1.000 & 7.000 & 4.000 & 3.000 & 4.000 & 5.000 & 3.000 & 4.833 & 1.000 \\
\hline LAW2 & 953 & 6.326 & 0.817 & 3.980 & 8.020 & 6.289 & 5.835 & 7.888 & 6.643 & 6.690 & 7.285 & 4.617 \\
\hline CRISIS & 964 & 13.674 & 5.654 & 3.107 & 34.634 & 5.058 & 18.976 & 20.913 & 11.729 & 11.041 & 14.332 & 11.630 \\
\hline \multicolumn{13}{|c|}{ Alternative extra-bank determinants } \\
\hline GDP & 964 & 0.030 & 0.040 & -0.109 & 0.183 & 0.044 & 0.034 & 0.037 & 0.023 & 0.025 & 0.051 & 0.020 \\
\hline BANKDEP & 964 & 29.188 & 14.334 & 12.945 & 87.774 & 21.091 & 46.428 & 50.107 & 22.915 & 20.354 & 24.388 & 18.706 \\
\hline FOREIGNBANK & 964 & 0.445 & 0.145 & 0.100 & 0.900 & 0.350 & 0.347 & 0.447 & 0.466 & 0.582 & 0.596 & 0.206 \\
\hline CIR & 964 & 67.943 & 11.310 & 46.726 & 92.247 & 74.106 & 61.709 & 54.170 & 64.874 & 81.497 & 57.549 & 63.092 \\
\hline STOCКМКТО & 910 & 20.549 & 21.082 & 0.000 & 90.791 & 11.820 & 46.082 & 16.635 & 26.455 & 3.610 & 8.771 & 3.257 \\
\hline CORRUPT & 964 & 3.068 & 1.102 & 1.300 & 7.500 & 2.922 & 3.791 & 7.121 & 3.421 & 1.765 & 3.731 & 2.353 \\
\hline LNGDPGROWTH & 964 & 1.297 & 0.815 & 0.185 & 6.854 & 2.171 & 1.377 & 1.773 & 1.754 & 0.344 & 0.892 & 1.630 \\
\hline
\end{tabular}

are the countries with the highest average net interest margins, whilst at the other extreme is Argentina. The rest of the countries have average margins. Venezuela and Paraguay have the highest capitalization ratio relative to the other countries included in the sample. The bank concentration (CONC1) climbs up to an average of 50\% of the assets in hand of the three largest banks by country for the sample during the period of analysis.

\subsection{Multivariate analysis}

The starting point of the empirical analysis was to check whether the panel data and the individual time series are stationary. Using a Fisher-type test, we find no evidence of a unit root in the series under consideration. To do so, we repeated the test performing the augmented Dickey-Fuller test as well as the Phillips-Perron test that the variables follow a unit-root process. In
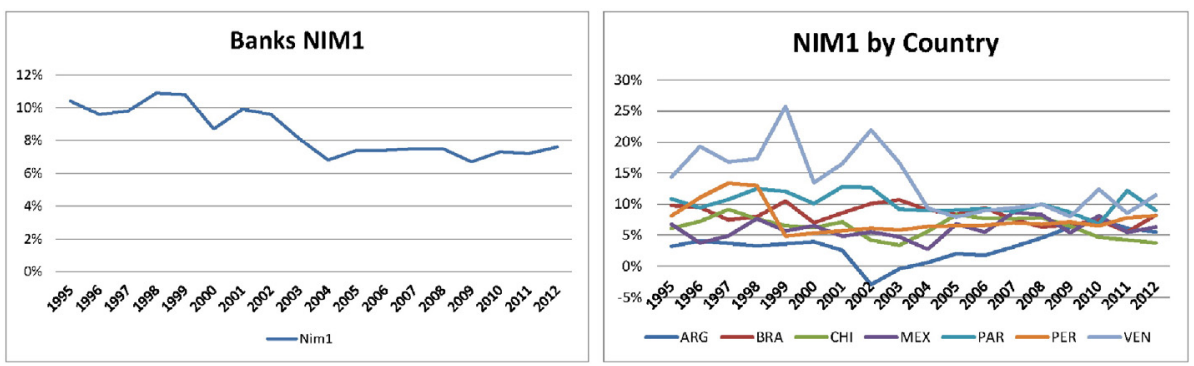

Exhibit 1. Evolution of the banks' profitability. These two graphs describe the evolution of the banks' profitability measured as the net interest margin (NIM1). The first graph provides the description of this variables along the period of analysis whilst the second graph describes the evolution of the NIM1 per country along the period of analysis. 
all the cases, we found that the variables were generated by a stationary process. These tests are in accordance with most of the literature which assumes stationarity in the banking industry.

Table 3 displays the regressions between the independent variables and the banks' profitability (NIM1). In all the regressions we observe that the independent variables are jointly significant, according to the Wald test. There is no a second-order autocorrelation among the variables, despite the fact that in some regressions there is first order autocorrelation. Nevertheless, this fact does not invalidate our results (Arellano \& Bond, 1991). Regarding to the moment conditions, the Hansen test did not reject the overidentifying

Table 3

Regression analysis.

The sample includes banks from Argentina, Brazil, Chile, Mexico, Paraguay, Peru, and Venezuela. The period of analysis is 1995-2012. The table shows the regression results for the GMM System Estimator. The NIM1 is the net interest margin which corresponds to the dependent variable; CAP is the capital ratio; DIVERSIF1 and DIVERSIF2 are two alternative measures for the asset and revenue diversification, respectively; SIZE measures the bank's size; CREDRISK1 is the loan loss provision over total assets; CONS2 measures the bank concentration; LOAN is the banks loans; DEPTA is the deposit over total assets; INFL is the annual inflation rate; GDPGROWTH is GDP per capita growth; FINDEV1 and FINDEV2 are two alternative measures for the development of the financial system where the first one is based on the market capitalization and the second on the private credit by deposit money banks; RESERVE is a proxy for the reserve requirements; LAW1 is a proxy for the legal and regulatory system; and CRISIS is a measure of the impact of the crises in the banking industry along the period of analysis. The Critical Value is the threshold in the capital ratio at which the profitability (NIM1) is maximized. AR(1) and AR(2) correspond to the first- and second-order serial correlation tests using residuals in first differences, asymptotically distributed as $\mathrm{N}(0,1)$ under the null of no serial correlation. The Hansen test of overidentifying restrictions is asymptotically distributed as Chi-square under the null of no relation between the instruments and the error term. The Wald test is a Chi-square test of the joint significance of all of the variables considered in the analysis. Lind-Mehlum's test is used to verify the inverse U-shaped relationship between the NIM1 and CAP. Standard errors are located beneath the regression coefficients. ${ }^{*}, * *$ and ${ }^{* * *}$ indicate significance at the 10,5 and $1 \%$ levels, respectively.

\begin{tabular}{|c|c|c|c|c|}
\hline \multirow[t]{2}{*}{ Variables } & \multirow{2}{*}{$\frac{\text { Coeff. }}{\text { Std. error }}$} & \multirow{2}{*}{$\frac{\text { Coeff. }}{\text { Std. error }}$} & \multirow{2}{*}{$\frac{\text { Coeff. }}{\text { Std. error }}$} & \multirow{2}{*}{$\frac{\text { Coeff. }}{\text { Std. error }}$} \\
\hline & & & & \\
\hline \multirow[t]{2}{*}{ Intercept } & $0.0378^{* * *}$ & $0.0515^{* * *}$ & $0.0155^{* * *}$ & $0.0382^{* * *}$ \\
\hline & 0.0051 & 0.0057 & 0.0039 & 0.0051 \\
\hline \multirow[t]{2}{*}{$\mathrm{NIM} 1_{t-1}$} & $0.4037^{* * *}$ & $0.4332^{* * *}$ & $0.4077^{* * *}$ & $0.4157^{* * *}$ \\
\hline & 0.0058 & 0.0059 & 0.0108 & 0.0070 \\
\hline \multirow[t]{2}{*}{ CAP } & $0.0985^{* * *}$ & $0.0685^{* * *}$ & $0.1145^{* * *}$ & $0.1129^{*}$ \\
\hline & 0.0093 & 0.0124 & 0.0183 & 0.0205 \\
\hline \multirow[t]{2}{*}{$\mathrm{CAP}^{2}$} & $-0.4403^{* * *}$ & $-0.4615^{* * *}$ & $-0.4881^{* * *}$ & $-0.4767^{* * *}$ \\
\hline & 0.0122 & 0.0311 & 0.0364 & 0.0418 \\
\hline Critical Value & 0.1119 & 0.0742 & 0.1173 & 0.1184 \\
\hline \multirow[t]{2}{*}{ DIVERSIF1 } & $0.0195^{* * *}$ & & $0.0217^{* *}$ & \\
\hline & 0.0020 & & 0.0013 & \\
\hline \multirow[t]{2}{*}{ DIVERSIF2 } & & $-0.0380^{* * *}$ & $* * *$ & $-0.0447^{* * *}$ \\
\hline & & 0.0010 & & 0.0011 \\
\hline \multirow[t]{2}{*}{ SIZE } & $0.0044^{* * *}$ & $0.0049^{* * *}$ & $0.0017^{* * *}$ & $0.0027^{* * *}$ \\
\hline & 0.0003 & 0.0003 & 0.0003 & 0.0003 \\
\hline \multirow[t]{2}{*}{ CREDRISK1 } & $0.0449^{* *}$ & $0.0517^{* *}$ & $0.0575^{*}$ & $0.0633^{* * *}$ \\
\hline & 0.0028 & 0.0035 & 0.0015 & 0.0031 \\
\hline \multirow[t]{2}{*}{ CONS2 } & $0.0032^{* *}$ & 0.0029 & $0.0118^{* * *}$ & $0.0148^{* * *}$ \\
\hline & 0.0016 & 0.0022 & 0.0019 & 0.0015 \\
\hline \multirow[t]{2}{*}{ LOAN } & $0.0659^{* * *}$ & $0.0591^{* * *}$ & $0.0241^{* * *}$ & $0.0208^{* * *}$ \\
\hline & 0.0019 & 0.0018 & 0.0022 & 0.0017 \\
\hline \multirow[t]{2}{*}{ DEPTA } & $0.0038^{*}$ & $0.0141^{* * *}$ & $0.0320^{*}$ & $0.0476^{* * *}$ \\
\hline & 0.0017 & 0.0014 & 0.0019 & 0.0030 \\
\hline \multirow[t]{2}{*}{ INFL } & $0.0197^{* *}$ & $0.0228^{* * *}$ & & \\
\hline & 0.0013 & 0.0013 & & \\
\hline \multirow[t]{2}{*}{ GDPGROWTH } & $-0.0665^{* * *}$ & $-0.0460^{* * *}$ & $-0.0576^{* * *}$ & $-0.0460^{* * * *}$ \\
\hline & 0.0016 & 0.0011 & 0.0026 & 0.0010 \\
\hline \multirow[t]{2}{*}{ FINDEV1 } & $0.0001^{* *}$ & $-0.0001^{* * *}$ & $-0.0005^{* * *}$ & $-0.0005^{* * *}$ \\
\hline & 0.0001 & 0.0001 & 0.0001 & 0.0003 \\
\hline \multirow[t]{2}{*}{ FINDEV2 } & $-0.0006^{* * *}$ & & & \\
\hline & 0.0002 & & & \\
\hline \multirow[t]{2}{*}{ RESERVE } & $0.0063^{* * * *}$ & $-0.0063^{* * *}$ & $0.0252^{*}$ & 0.0016 \\
\hline & 0.0017 & 0.0021 & 0.0029 & 0.0032 \\
\hline \multirow[t]{2}{*}{ LAW1 } & $-0.0138^{* * *}$ & $-0.0120^{* * *}$ & & \\
\hline & 0.0007 & 0.0007 & & \\
\hline \multirow[t]{2}{*}{ CRISIS } & $0.0397^{* *}$ & $0.0383^{* *}$ & $0.0340^{*}$ & 0.0164 \\
\hline & 0.0079 & 0.0110 & 0.0094 & 0.0041 \\
\hline Country dummy & Yes & Yes & Yes & Yes \\
\hline Time dummy & Yes & Yes & Yes & Yes \\
\hline $\operatorname{AR}(1)$ & $-3.420^{* *}$ & $-3.410^{* * *}$ & $-3.400^{* * *}$ & $-3.420^{* * *}$ \\
\hline $\operatorname{AR}(2)$ & -0.57 & -0.25 & -0.64 & -0.15 \\
\hline Hansen & 113.08 & 119.58 & 120.21 & 125.45 \\
\hline Wald & $1,145,406^{* * *}$ & $448,322^{* * *}$ & $5,474,550^{* * *}$ & $517,877^{* * *}$ \\
\hline Lind-Mehlum & $32.488^{* *}$ & $38.158^{* * *}$ & $45.715^{* * *}$ & $54.190^{* *}$ \\
\hline OBS & 955 & 955 & 955 & 955 \\
\hline
\end{tabular}


restrictions, meaning that the set of instruments is orthogonal to the estimated residuals. Thus, the results reported in Table 3 (and in all the reported tables afterwards) are robust according to standard diagnostic tests for panel data.

The results described in Table 3 show that there is an inverse U-shaped relationship between the capital to assets ratio and banks' performance measured by the net interest margin as the net interest revenue over the average earning assets (NIM1). This non-monotonic relationship is statistically significant according to the Lind and Mehlum (2010) test in all the estimations. The signaling hypothesis is a forward looking hypothesis on the performance of banks which supports a positive relation with capitalization. Under this hypothesis, managers will be willing to disclose valuable information to the markets concerning positive future prospects and a better capacity to generate cash flows and profits. Therefore, those banks expecting to improve their performance, might exhibit less debt in their financial statements, or in other words, higher capitalization ratios. The traditionally tested signaling hypothesis suggests that as the information between managers and investors is shared asymmetrically, it can be less costly for managers of low risk banks to signal the bank's quality through high capital ratios than for managers of high risk banks, suggesting a positive relationship between the capital-asset ratio and the bank's profitability (Berger, 1995b). Additionally, the expected bankruptcy costs hypothesis also supports the positive bank performance-capitalization relationship. This hypothesis postulates that financial institutions will increase their capitalization whenever the exogenous factors increasing the expected bankruptcy costs are greater. This is a protective measure against the likelihood of default.

The findings also show that the relationship between banks' performance and their capitalization ratio is negative. The traditional view of bank profitability suggests that an excessively high capitalization is associated with both a decrease in the risk of equity and the tax subsidy provided by interest deductibility on debt. Therefore, a bank with a high capital to assets ratio might denote that it is operating with overcautious policies. An overly conservative management might not be taking advantage of certain market opportunities and consequently experiencing lower performance.

Finally, the non-linear performance-capitalization relationship might also be supported by the trade-off theory (Saunders \& Schumacher, 2000). Under this paradigm, the greater the use of debt - less equity capital in the financial statements - the greater the interest expense will be and the higher the probability that the bank will be unable to meet its financial duties. Consequently, the required rate of return by new incoming shareholders or saver units will increase to reflect the higher probability of bankruptcy which reduces the banks' profitability.

The results reported in Table 3 describe that the profitability increases up to a certain threshold as capital increases. This critical point is estimated optimizing the net interest margin as a function of the capitalization ratio. ${ }^{12}$ Beneath the $C A P^{2}$ variable in Table 3 the optimal level of capitalization which maximizes the profitability (NIM1) is displayed. The findings show that, at an average level of equity capital of about $10.54 \%$ of total assets - computed as the mean among the critical values shown in the four regressions in Table 3 - the net interest margin is maximized for the Latin American banks included in the sample. This level is slightly lower than the average capital ratio (11.70\%) displayed in Table 2, suggesting that most of the banks are actually operating at capital levels close to the optimal ratio.

The findings seem to show that there is a differential relationship between functional diversification and profitability. The asset diversification (DIVERSIF1) enters the estimations positively, but the revenue diversification (DIVERSIF2), negatively. It seems to show that assets different from loans are a source of profitability; whilst inflows coming from non-interest income impact negatively on the performance of banks. Even though banks in Latin America have followed the global trend of performing non-interest income activities such as foreign exchange, investment banking, and securities trading, among many others, it seems to be that these activities cause a negative impact on the performance of banks. However, asset diversity such as that from derivatives and remaining earning assets are a source of value which impact positively the performance of banks. If we compare the coefficients of DIVERSIF1 and DIVERSIF2, we can observe that small changes in asset diversification impact relatively less on the net interest margins than revenue diversification.

The size (SIZE) of banks also has a positive relationship with the net interest margin. Consequently, economies of scale are observed in the Latin American banking industry. The larger the bank is, the larger the dimension of the operations the bank incurs and therefore the higher the risk, and thus the bank will charge higher margins impacting positively on profitability. This finding is in the same line as those found by Maudos and Solís (2009) for Mexican banks. Our results could also be interpreted as evidence that if banks are operating in the increasing returns portion of their average cost curve, bank profits are also positively affected (Demirgüç-Kunt et al., 2004).

The credit risk (CREDRISK1) impacts significantly upon the estimations, positively affecting the profitability. It seems to be that banks with greater loan-loss provisions as a percentage of gross loans will require a higher net interest margin to compensate for the greater default risk. In institutional settings where the interest of investors is weakly protected such as in Latin America, we observe that banks transfer the cost of higher risk to the customer who, ultimately, pays higher prices for the banking services. The great propensity toward financial crises in the region makes the credit risk a critical variable in explaining the profitability of banks. As a matter of fact, a small change in CREDRISK1 will impact the net interest margin 10 times more than a small change in the banks' size (e.g. the coefficient of CREDRISK1 and SIZE are 0.0449 and 0.0044 in the first estimation of Table 3, respectively). This finding is in line with those found for a sample of Brazilian banks by Almeida and Divino (2015). Particularly, these authors find that higher administrative costs are passed on to borrowers, increasing the banks' rates of spread. We find that the credit risk

\footnotetext{
12 The computation of the critical value in the first regression of Table 3 is done by calculating the first derivative of this regression with respect to the CAP variable, and then making it equal to zero. Subsequently, we have to solve for CAP which represents the point at which the profitability is maximized. More specifically, for instance, for the first regression this solution takes the form: $\frac{\partial N I M 1}{\partial C A P}=0.0985+2(-0.4403 C A P)=0$. Consequently, when CAP $=11.19 \%$ the bank's profitability is maximized. Idem calculations were done for all the other regressions which include $C A P^{2}$.
} 
is related to bank concentration, measured by the market power variable (CONS2). Emerging economies are characterized for having less developed financial markets with most of the intermediary activity concentrated in a handful of banks or financial institutions which can charge higher prices than those in competitive markets. Recall that since the mid-90s the banking sector in Latin America experienced profound changes due to financial liberalization, to the increase in foreign investments, and to greater merger activities which often occurred after periods of financial crises (Feldmann, 2012; Singh et al., 2005; Yeyati \& Micco, 2007). All this drove a substantial market concentration in a few large banks with its subsequent increase in their market power. The results show that when concentration increases, the profitability of banks also increases. This result is in line with the recent findings of Almeida and Divino (2015). They find that more concentrated environments might reflect higher market power which leads to higher spreads. In other words, banks exercise their monopolistic power obtaining abnormal profits that, otherwise, would not exist in more competitive environments.

There is a positive and statistically significant relationship between bank loans (LOAN) and performance. This means that banks take advantage of economies of scale in order to improve their profitability. Chortareas et al. (2011), however, do not find this variable statistically significant in their empirical analysis for Latin America. The lack of competitive conditions in the banking industry in Latin America leads banks to finance their activities with higher proportions of custom deposits (DEPTA). In that sense, deposits constitute a cheap source of funds compared with other financing alternatives, improving the performance of banks.

Regarding the set of extra-bank determinants of the bank performance, our findings suggest that as the stock market capitalization as a percentage of the GDP (FINDEV1) increases, the bank performance lowers. This variable is a proxy for financial development, which indicates that countries with developed stock markets have more competitive environments that press down on bank interest margins (Demirgüç-Kunt \& Levine, 2004). Contrary to these arguments, the recent work of Ben Naceur and Omran (2011) suggests that stock market development impacts positively on bank performance, particularly in countries at low stages of financial development. Our findings seem to support the hypothesis that more developed capital markets create a more competitive environment which limits the abnormal profits of banks instead.

One additional alternative measure of financial development used in this work is the credit to the private sector as a percentage of the GDP (FINDEV2). The results, based on this variable are also in line with those of FINDEV1. Credit to the private sector impacts the performance of banks negatively. This finding supports the hypothesis that the greater availability of credit to the corporate sector in the economy is linked to higher competition and more developed banking sectors, leading to lower net interest margins (Sanyal \& Shankar, 2011).

Legal enforcement ( $L A W 1$ ) enters the estimations significantly. We observe that legal environments associated with higher levels of protection of investors allow the markets to perform with fewer frictions, according to our hypothesis. Consequently, lower abnormal profits and net interest margins are observed as legal enforcement improves. This finding is also correlated with the economic freedom index ( $L A W 2$ ) which showed a negative correlation with bank performance.

Among the control variables, Table 3 shows that inflation rates (INFL) are fully anticipated by managers, which cause earnings to increase faster than costs, improving the net interest margins. This is not a surprising finding because in Latin America most of the economies have suffered periods of high inflation, and consequently banks have burdened clients with higher spreads for their banking services. What is surprising is that the growth of the Gross Domestic Product per capita (GDPGROWTH) in the region impacts negatively on the net interest margin of the banking industry. This is somehow a peculiar finding because one would expect that the demand for credit from both households and firms might positively impact the performance of banks. Nevertheless, it appears that in periods of substantial economic growth, banks adjust by reducing their margins. Apparently, improved performance of the economy fosters market conditions that make them more competitive and therefore the abnormal profits in the banking industry are minimized.

Following Ben Naceur and Omran (2011) we used the ratio of non-interest earning assets over total assets as a proxy for reserve requirements (RESERVE). Recall that the costs of reserves are considered as a tax on bank operating activities, and, therefore, the cost of reserve requirement is the opportunity cost of keeping such reserves. In two out of the four regressions the results support a positive relationship between the costs of reserve and the bank performance. This means that the average bank in Latin America tries to reflect this tax (opportunity cost of reserves) by increasing its explicit margins and passing it on to customers. Therefore, the demand for banking products is impelled to pay higher prices than competitive prices as the cost of reserve increases. Nevertheless, we must be cautious with this finding because in one regression the sign of the coefficient was negative.

As can be seen in the first three regressions, the coefficient of the variable which measures the impact of the financial crises (CRISIS) in the banking industry is positive and statistically significant. By construction of this variable, this means that during periods of economic contractions bank performance drops.

The comparison of the coefficients of the variables different than the intra-bank determinants suggests that GDPGROWTH $(-0.0665$ in column 1$)$, followed by CRISIS (0.0397) and the INFL (0.0197) are the variables with the highest impact on the net interest margin.

Briefly, considering the extra-bank determinants of profitability, it can be concluded that, when the economy performs with less friction in its financial markets and under a sound enforcement of the legal and institutional systems, the profits made by the financial institutions look more like the profits of competitive markets.

\subsection{Principal component analysis}

Since the number of extra-bank determinants and control variables is large (16) relative to the number of countries included in the sample and because the correlation between these variables is high in certain cases, we cannot enter them all together in the 
Table 4

Principal component analysis of extra-bank determinants.

The table summarizes the variables used to compute the three factors as composite indexes of the extra-bank determinants of the banks' profitability (Macroeconomic Environment, Financial Development, and Regulatory System). Descriptions about the computation of each variable are detailed in Section 3.2.

\begin{tabular}{|c|c|c|c|c|}
\hline Component name & $\%$ variance & Eigen value & Original variable & Component matrix \\
\hline \multirow[t]{4}{*}{ Macroeconomic Environment } & 70.07 & 1.102 & GDP & 0.449 \\
\hline & & & INFL & 0.449 \\
\hline & & & GDPGROWTH & 0.000 \\
\hline & & & CRISIS & 0.479 \\
\hline \multirow[t]{7}{*}{ Financial Development } & 76.9 & 4.61 & FINDEV1 & 0.175 \\
\hline & & & FINDEV2 & 0.510 \\
\hline & & & BANKDEP & 0.088 \\
\hline & & & FOREIGNBANK & 0.213 \\
\hline & & & CONC1 & 0.177 \\
\hline & & & CIR & 0.180 \\
\hline & & & STOCKMKTO & 0.196 \\
\hline \multirow[t]{5}{*}{ Regulatory System } & 79.59 & 2.12 & RESERVE1 & 0.409 \\
\hline & & & LAW1 & 0.206 \\
\hline & & & LAW2 & 0.414 \\
\hline & & & CORRUPT & 0.289 \\
\hline & & & LNGDPGROWTH & 0.114 \\
\hline
\end{tabular}

same regression. In order to address this issue in modeling the bank's performance, we decided to apply the principal component factoring technique to take advantage of the informational content of all the variables.

The major benefits of this technique are that the factors created are not correlated, on the one hand, and the factors record a large extent of the variability of the individual variables used in the estimation of the factors on the other hand (Kim \& Mueller, 1978). Table 4 displays the number of factors generated for the variables used in the model. The factor analysis shows that the first factor, named Macroeconomic Environment, achieved an Eigen value higher than the unit (1.102) as the standard discrimination value and that this factor records more than $70.07 \%$ of the variance of the variables included in the factor. This factor includes the following variables: Gross Domestic Product (GDP), inflation rate (INFL), GDP per capita (GDPGROWTH), and periods of economic crises (CRISIS). The second factor is the Degree of Financial Development, which explains 76.90\% of the variance of the variables market capitalization (FINDEV1), credit to private sector as a share of GDP (FINDEV2), bank deposits over GDP (BANKDEP), the percentage of foreign banks among total banks (FOREINGBANK), the assets of the three largest banks as a share of assets of all commercial banks (CONC1), the operating efficiency measured as total costs as a share of total income of all commercial banks $(C I R)$, and the stock market turnover ratio ${ }^{13}$ (STOCKMKTO). Finally, the Regulatory System factor comprises the variables RESERVE1, $L A W 1$, and CORRUPT which is based on the Perception Index of Transparency and Corruption, LNGDPGROWTH which is the natural logarithm of GDPGROWTH as a measure of institutional development, and the economic freedom index (LAW2), explaining 79.59\% of their variance.

Regressions in Table 5 include as extra-bank determinants the set of these three factors which are used as consistency tests of our previous findings. In this table, we can observe that the non-monotonic relationship between banks' capitalization and performance is optimized at a level of capital of $15.45 \%$ of total assets (see footnote 12 for further details on the computation of the critical value), calculated as the average of the four regressions shown in Table 5. In other words, bank performance increases when more internal capital is used to finance the operations. Nevertheless, when banks use excessive capital, there is a negative impact on performance, as predicted by the theory. The results also support the fact that the functional diversification in Latin American banks is a source of value. New business opportunities not explored in previous decades, such as investment banks, securities trading, hedge funds, foreign exchange markets, and assurance, among many others, are now profitable businesses. Most of these new business options are a source of modernization of the banking industry as a result of their mergers and acquisitions with foreign banks.

The size of the bank, as well as the amount of loans as a proportion of total assets, and the deposits demanded by customers still show a positive relationship with the performance variable, in the same way as discussed in the previous section. Therefore, the larger dimension of the bank (SIZE) and its capacity to both, finance the operations of productive sectors (LOAN) and collect sources from saving units (DEPTA) impact positively its performance.

Concerning credit risk and the market power generated by its concentration, our results show that banks with riskier loans will use their market power to require higher net interest margins to the ultimate customers to compensate for the greater risk of default. In other words, although there have been important advances that have made banking systems more competitive in Latin America over the last decades, there is still a strong concentration in the banking industry. This fact makes banks have to work with several monopolistic characteristics, particularly in the prices charged for their banking services, the quality of their

\footnotetext{
13 The stock market turnover ratio corresponds to the value of total shares traded to average real market capitalization. The denominator is deflated using the following method: $\frac{T_{t}}{T}$ where $T$ is total value traded, $M$ is the stock market capitalization, $P_{e}$ is the end-of period Consumer Price Index and $P_{a}$ is the average annual $\left(\frac{P_{a t}}{0.5 *\left[\frac{M_{t}}{P_{\text {et }}}+\frac{M_{t-1}}{P_{\text {et }}-1}\right]}\right)$

Consumer Price Index.
} 
Table 5

Regression analysis. Extra-bank determinants are comprised in three factors.

The sample includes banks from Argentina, Brazil, Chile, Mexico, Paraguay, Peru, and Venezuela. The period of analysis is 1995-2012. The table shows the regression results for the GMM System Estimator. The NIM1 is the net interest margin, which corresponds to the dependent variable; CAP is the capital ratio; DIVERSIF1 measures the asset diversification; SIZE measures the bank's size; CREDRISK1 is the loan loss provision over total assets; CONS2 measures the bank concentration; LOAN is the bank loans; and DEPTA is the deposit over total assets. Macroeconomic Environment, Financial Development and Regulatory Systems are extra-bank determinants of bank profitability which are based on the results from the Factor Analysis of Table 4. The Critical Value is the threshold in the capital ratio at which the profitability (NIM1) is maximized. AR(1) and AR(2) correspond to the first- and second-order serial correlation tests using residuals in first differences, asymptotically distributed as $\mathrm{N}(0,1)$ under the null of no serial correlation. The Hansen test of overidentifying restrictions is asymptotically distributed as Chi-square under the null of no relation between the instruments and the error term. The Wald test is a Chi-square test of the joint significance of all of the variables considered in the analysis. Lind-Mehlum's test is used to verify the inverse U-shaped relationship between the NIM1 and CAP. Standard errors are located beneath the regression coefficients. * ** and *** indicate significance at the 10,5 and $1 \%$ levels, respectively.

\begin{tabular}{|c|c|c|c|c|}
\hline & \multirow{2}{*}{$\frac{\text { Coeff. }}{\text { Std. error }}$} & \multirow{2}{*}{$\frac{\text { Coeff. }}{\text { Std. error }}$} & \multirow{2}{*}{$\frac{\text { Coeff. }}{\text { Std. error }}$} & \multirow{2}{*}{$\frac{\text { Coeff. }}{\text { Std. error }}$} \\
\hline & & & & \\
\hline \multirow[t]{2}{*}{ Intercept } & $-0.0415^{* * *}$ & $-0.0392^{* * *}$ & $-0.0307^{* * *}$ & $-0.0164^{* * *}$ \\
\hline & 0.0021 & 0.0033 & 0.0040 & 0.0041 \\
\hline \multirow{2}{*}{$\mathrm{NIM} 1_{\mathrm{t}-1}$} & $0.5336^{* * *}$ & $0.5551^{* * *}$ & $0.5404^{* * *}$ & $0.5047^{* * *}$ \\
\hline & 0.0174 & 0.0058 & 0.0084 & 0.0074 \\
\hline \multirow[t]{2}{*}{ CAP } & $0.1107^{* * *}$ & $0.0862^{*}$ & $0.0722^{* * *}$ & $0.0667^{* *}$ \\
\hline & 0.0042 & 0.0088 & 0.0080 & 0.0091 \\
\hline \multirow[t]{2}{*}{$\mathrm{CAP}^{2}$} & $-0.3639^{* * *}$ & $-0.3962^{* * *}$ & $-0.1982^{* * *}$ & $-0.1908^{* * *}$ \\
\hline & 0.0109 & 0.0218 & 0.0163 & 0.0073 \\
\hline Critical Value & 0.1521 & 0.1087 & 0.1822 & 0.1748 \\
\hline \multirow[t]{2}{*}{ DIVERSIF1 } & $0.0246^{* * *}$ & $0.0365^{* * *}$ & $0.0363^{* * *}$ & $0.0226^{* * *}$ \\
\hline & 0.0011 & 0.0007 & 0.0009 & 0.0017 \\
\hline \multirow[t]{2}{*}{ SIZE } & $0.0052^{* * *}$ & $0.0043^{* * *}$ & $0.0036^{* * *}$ & $0.0034^{* *}$ \\
\hline & 0.0002 & 0.0002 & 0.0003 & 0.0003 \\
\hline \multirow[t]{2}{*}{ CREDRISK1 } & $0.0416^{*}$ & $0.0713^{* *}$ & $0.0741^{*}$ & $0.0431^{*}$ \\
\hline & 0.0021 & 0.0021 & 0.0018 & 0.0048 \\
\hline \multirow[t]{2}{*}{ CONS2 } & $0.0028^{* * *}$ & $0.0106^{* * *}$ & $0.0057^{* * * *}$ & $0.0084^{* * *}$ \\
\hline & 0.0010 & 0.0010 & 0.0010 & 0.0017 \\
\hline \multirow[t]{2}{*}{ LOAN } & $0.0378^{*}$ & $0.0389^{* * *}$ & $0.0355^{* * *}$ & $0.0321^{*}$ \\
\hline & 0.0019 & 0.0013 & 0.0010 & 0.0028 \\
\hline \multirow[t]{2}{*}{ DEPTA } & $0.0211^{* * *}$ & $0.0259^{* * * *}$ & $0.0279^{* * *}$ & $0.0235^{* * *}$ \\
\hline & 0.0006 & 0.0009 & 0.0009 & 0.0024 \\
\hline \multirow[t]{2}{*}{ Macroecon. Environment } & $0.0077^{* * *}$ & & & $0.0085^{* * *}$ \\
\hline & 0.0001 & & & 0.0001 \\
\hline \multirow[t]{2}{*}{ Financial Development } & & $0.0097^{* *}$ & & $0.0239 * *$ \\
\hline & & 0.0016 & & 0.0044 \\
\hline \multirow[t]{2}{*}{ Regulatory System } & & & $-0.0105^{* * *}$ & $-0.0238^{* * *}$ \\
\hline & & & 0.0009 & 0.0019 \\
\hline Country dummy & Yes & Yes & Yes & Yes \\
\hline Time dummy & Yes & Yes & Yes & Yes \\
\hline $\operatorname{AR}(1)$ & $-3.580^{* * *}$ & $-3.390^{* * *}$ & $-3.370^{* * *}$ & $-3.590^{* * *}$ \\
\hline $\operatorname{AR}(2)$ & -0.55 & -0.58 & -0.57 & -0.51 \\
\hline Hansen & 127.69 & 124.53 & 124.02 & 128.26 \\
\hline Wald & $4.50 \mathrm{E}+06^{* *}$ & $1.70 \mathrm{E}+06^{* * *}$ & $1.05 \mathrm{E}+06^{* * *}$ & $1.50 \mathrm{E}+05^{* *}$ \\
\hline Lind-Mehlum & $74.845^{* *}$ & $70.186^{* * *}$ & $50.478^{* * *}$ & $54.680^{* *}$ \\
\hline OBS & 964 & 964 & 964 & 964 \\
\hline
\end{tabular}

product mix, their bargaining power, and their preference for financing certain economic sectors to the detriment of others (Chortareas et al., 2011).

Finally, our results in Table 5 show that each factor compounding the set of extra-bank determinants of bank profitability are statistically significant. Therefore, we can confirm that, undoubtedly, we cannot ignore the fact that the performance of banks is linked to other external factors such as the Macroeconomic Environment, the current Financial Development of the country, and the Regulatory and Legal System where banks operate.

\subsection{Robustness analysis}

This final part of our analysis corresponds to the robustness checks of our findings. In order to do so, the results of the last regression in Table 5 were replicated with our three alternative measures of bank performance (NIM2, NIM3 and NIM4) as dependent variables in Table 6 . In general, the results in Table 6 not only broadly confirm the previous findings, but also provide some more support for the importance of extra-bank determinants. In all the cases the Macroeconomic Environment, Financial Development and the Regulatory System enter the regressions statistically significant and with the same signs. From these three variables, the development of the financial system is the one with the highest impact on the profitability of banks. Consequently, a key implication of these findings is that when higher barriers to competition exist and the financial markets are less developed, the intermediation costs increase and consumers are worse off. These findings are also supported by the concentration of (CONC2) and (CREDRISK1) 
Table 6

Regression analysis. Robustness check.

The sample includes banks from Argentina, Brazil, Chile, Mexico, Paraguay, Peru, and Venezuela. The period of analysis is 1995-2012. The table shows the regression results for the GMM System Estimator. The dependent variables which correspond to the banks' profitability are NIM2, NIM3, and NIM4; CAP is the capital ratio; DIVERSIF1 measures the asset diversification; SIZE measures the bank's size; CREDRISK1 is the loan loss provision over total assets; CONS2 measures the bank concentration; LOAN is the bank loans; and DEPTA is the deposit over total assets. Macroeconomic Environment, Financial Development and Regulatory Systems are extrabank determinants of bank profitability which are based on the results from the Factor Analysis of Table 4. The Critical Value is the threshold in the capital ratio at which the profitability is maximized. AR(1) and $\mathrm{AR}(2)$ correspond to the first- and second-order serial correlation tests using residuals in first differences, asymptotically distributed as $\mathrm{N}(0.1)$ under the null of no serial correlation. The Hansen test of overidentifying restrictions is asymptotically distributed as Chi-square under the null of no relation between the instruments and the error term. The Wald test is a Chi-square test of the joint significance of all of the variables considered in the analysis. LindMehlum's test is used to verify the inverse U-shaped relationship between the different alternative measures of banks' profitability and CAP. Standard errors are located beneath the regression coefficients. ${ }^{*}, * *$ and ${ }^{* * *}$ indicate significance at the 10,5 and $1 \%$ levels, respectively.

\begin{tabular}{|c|c|c|c|}
\hline \multirow[t]{3}{*}{ Variables } & \multirow{2}{*}{$\frac{\text { NIM2 }}{\text { Coeff. }}$} & \multirow{2}{*}{$\frac{\text { NIM3 }}{\text { Coeff. }}$} & \multirow{2}{*}{$\frac{\text { NIM4 }}{\text { Coeff. }}$} \\
\hline & & & \\
\hline & Std. error & Std. error & Std. error \\
\hline \multirow[t]{2}{*}{ Intercept } & $0.0172^{* *}$ & $0.0063^{* * *}$ & $-0.0041^{* * *}$ \\
\hline & 0.0012 & 0.0024 & 0.0035 \\
\hline \multirow{2}{*}{ Dependent variable $_{t-1}$} & $0.4990^{* * *}$ & $0.3490^{* *}$ & $0.2850^{* * *}$ \\
\hline & 0.0049 & 0.0080 & 0.0056 \\
\hline \multirow[t]{2}{*}{ CAP } & $0.1051^{* * *}$ & $0.0291^{* *}$ & 0.0134 \\
\hline & 0.0057 & 0.0071 & 0.0109 \\
\hline \multirow[t]{2}{*}{$\mathrm{CAP}^{2}$} & $-0.2801^{* * *}$ & $-0.1601^{* * *}$ & $0.1830^{* * *}$ \\
\hline & 0.0133 & 0.0178 & 0.0202 \\
\hline Critical Value & 0.1875 & 0.0909 & - \\
\hline \multirow[t]{2}{*}{ DIVERSIF1 } & 0.0122 & $0.0161^{*}$ & 0.0278 \\
\hline & 0.0303 & 0.0009 & 0.0736 \\
\hline \multirow[t]{2}{*}{ SIZE } & $0.0003^{* * *}$ & $0.0012^{* * *}$ & $0.0038^{* * *}$ \\
\hline & 0.0008 & 0.0002 & 0.0002 \\
\hline \multirow[t]{2}{*}{ CREDRISK1 } & $0.0195^{*}$ & $0.0654^{* * *}$ & 0.1030 \\
\hline & 0.0012 & 0.0027 & 0.0047 \\
\hline \multirow[t]{2}{*}{ CONS2 } & $0.0249^{* * *}$ & $0.0238^{* * *}$ & $0.0055^{* * *}$ \\
\hline & 0.0007 & 0.0009 & 0.0014 \\
\hline \multirow[t]{2}{*}{ LOAN } & $0.0153^{*}$ & 0.0253 & $0.0068^{* *}$ \\
\hline & 0.0008 & 0.0014 & 0.0016 \\
\hline \multirow[t]{2}{*}{ DEPTA } & 0.0165 & $0.0095^{* * *}$ & 0.0301 \\
\hline & 0.0117 & 0.0013 & 0.0014 \\
\hline \multirow[t]{2}{*}{ Macroecon. Environment } & $0.0027^{* * *}$ & $0.0029^{* * *}$ & $0.0049^{* * *}$ \\
\hline & 0.0011 & 0.0002 & 0.0002 \\
\hline \multirow[t]{2}{*}{ Financial Development } & $0.0096^{* * *}$ & $0.0121^{* *}$ & $0.0159^{*}$ \\
\hline & 0.0022 & 0.0052 & 0.0085 \\
\hline \multirow[t]{2}{*}{ Regulatory System } & $-0.0102^{* * *}$ & $-0.0125^{* * *}$ & $-0.0164^{* *}$ \\
\hline & 0.0007 & 0.0006 & 0.0016 \\
\hline Country dummy & Yes & Yes & Yes \\
\hline Time dummy & Yes & Yes & Yes \\
\hline $\mathrm{AR}(1)$ & $-4.320^{* * *}$ & $-3.880^{* * *}$ & $-3.020^{* * *}$ \\
\hline $\mathrm{AR}(2)$ & 0.270 & 0.632 & 0.50 \\
\hline Hansen & 112.90 & 151.22 & 148.50 \\
\hline Wald & $18,881.06^{* * *}$ & $1355.00^{* * *}$ & $10,712.02^{* * *}$ \\
\hline Lind-Mehlum & $18.260^{* * *}$ & $2.55 *$ & - \\
\hline OBS & 780 & 924 & 924 \\
\hline
\end{tabular}

variables. In both situations, we observe that the profitability of banks increases when the market is less competitive and when the risk in the banking industry increases. The consumer is therefore the ultimate one affected, supporting the burden of such market inefficiencies. Concerning the capital ratio, we observe that in two out of the three regressions the relationship with the banks' profitability seems to lead to an optimal level of equity capital which maximizes such profitability (NIM2 and NIM3). In the third regression, when the dependent variable is measured as the net interest revenue over total earning assets (NIM4) the capital ratio is statistically significant in its quadratic transformation $(C A P)^{2}$ only and enters the regression with a positive sign. This particular result supports the positive relationship between the profitability and capital ratio. In this case, the expected bankruptcy costs arguments seem to support this relationship, and consequently firms would incur in higher equity capital to minimize expected bankruptcy costs. The loss of significance in CAP variable might be due to the distribution of NIM4 variable. Out of the four variables used as alternative measures of net interest margin, NIM4 is the one with the highest skewness (1.74) which is greater than the expected value of zero for a normal distribution. Additionally, the kurtosis of this variable is also the highest among all the proxies for profitability, with a value of 6.76 indicative of heavy tails. Thus, since NIM4 has the less normal distribution among the dependent variables, the explanatory power of the independent variables is further ameliorated as in the case of CAP. Nevertheless, all our previous findings are strong enough to state that there is in fact an inverse U-shaped relationship between the capital ratio and the net interest margin.

Finally, although there is a certain loss of significance in some of the other variables, the results are still robust to these alternative specifications. 


\section{Conclusions}

The Latin American banking sector has experienced profound changes over the last few decades. The improvements of the banking services and its modernization have been inspired by the waves of mergers, acquisitions and takeovers by foreign banks, on the one hand, and by the openness of the local economies and changes to the regulatory systems on the other hand. Altogether, this has caused, among other matters, a high concentration of the banking system in the region, translated into high market power in a handful of banks which eventually has impacted the performance of the banking industry.

The goal of this paper has been, therefore, to evaluate the impact of the intra- and extra-bank drivers of profitability in a representative sample of Latin American banks over the 1995-2012 period. In our empirical analysis, we have applied a pragmatic approach that allows us to consider historical information per bank during the period of analysis.

The main findings uncover evidence supporting the nonlinear relationship between bank capitalization and its performance. It appears that performance improves as capital increases relative to a bank's total assets, but only up to a certain critical value where excessive capital becomes detrimental to the bank's profitability. The positive capital-performance relationship is supported by the expected bankruptcy costs and the signaling hypotheses. However, the negative impact of the capital ratio on performance is caused by the decrease in the tax subsidy provided through interest deductibility, on the one hand, and by the efficiency-risk hypothesis on the other hand.

Some other significant findings are linked to the functional diversification of the banking industry. We note that asset diversification in the banking sector in Latin America has a positive impact on its performance. Conversely, revenue diversification has a negative impact. Other internal determinants of bank profitability, such as bank size and the demand for deposits are also statistically significant. However, the addition of external determinants of bank performance in the reported model is perhaps the most significant finding. On the one hand, there is a clear negative impact of the efficiency of the regulatory systems on bank performance but on the other hand there is also a reduction in abnormal profits when the financial system improves.

As a result of these findings, we can derive direct policy implications. First, despite the significant development of financial markets over the last decades, we still observe high market power concentrated in only a few banks. Although the deregulation of the markets has taken place in most of the Latin American region, further measures to make the markets even more competitive are still required. The removal of the remaining barriers to competition should be expected to benefit the banking system without being detrimental to consumers, who currently pay higher prices for banking services in Latin America than in other more industrialized countries. Associated with this conclusion, our results also raise concern about the damaging effects of market concentration on consumers. Consequently, it is suggested that policy makers should promote more competition and a deconcentration of the banking industry across the countries in the region.

Additionally, as it was confirmed in the empirical analysis, an enhancement of regulation presses down the excessive profitability of the banks. As it is known, wider spreads for financial intermediation services imply that using the financial system might become prohibitive for a certain number of borrowers. Consequently, the role played by the legal and regulatory system is critical in avoiding excessive spreads from banks. To trigger the economic growth it is vital that consumers have fewer constraints to credit. Therefore, the policy implication derived out of this is that higher enforcement of the law and better regulations should aim to improve the efficiency of banking systems in Latin America.

Finally, as has been discussed throughout this work, there is no single factor impacting the profitability of banks in Latin America, and what is more, such impact on the performance does not come necessarily from managerial skills but also from the institutional environment where banks operate. Consequently, it is suggested that the measures taken by the Central Banks in the region should be primarily driven by prudential regulation and supervision tools over the traditional short-term monetary policy instruments as the most effective ways to ensure a convergence of the best practices in the local banking industry toward the international benchmarks.

\section{Acknowledgments}

I would like to thank the helpful comments and suggestions of David Howden, Kirk Tenant, Alesia Slocum and the seminal participants at the 14th International Finance Conference in Mexico (2014).

\section{References}

Afanasieff, T. S., Lhacer, P. M. V., \& Kanane, M. I. (2002). The determinants of bank interest spread in Brazil. Money Affairs, 15(2), $183-207$.

Allen, L. (1988). The determinants of bank interest margins: A note. Journal of Financial and Quantitative Analysis, 23(2), $231-235$.

Almeida, F. D., \& Divino, J. A. (2015). Determinants of the banking spread in the Brazilian economy: The role of micro and macroeconomic factors. International Review of Economics \& Finance, 40(1), 29-39. http://dx.doi.org/10.1016/j.iref.2015.02.003.

Alonso-Borrego, C., \& Arellano, M. (1999). Symmetrically normalized instrumental variable estimation using panel data. Journal of Business E’ Economic Statistics, 17(1), 36-49.

Angbazo, L. (1997). Commercial bank net interest margins, default risk, interest-rate risk, and off-balance sheet banking. Journal of Banking E’ Finance, 21(1), 55-87. http://dx.doi.org/10.1016/S0378-4266(96)00025-8.

Arellano, M. (2002). Sargan's instrumental variables estimation and the generalized method of moments. Journal of Business E' Economic Statistics, 20 (4), 450-459.

Arellano, M., \& Bond, S. (1991). Some tests of specification for panel data: Monte Carlo evidence and an application to employment equation. The Review of Economic Studies, 58(2), 277-297.

Athanasoglou, P., Brissimis, S., \& Delis, M. (2008). Bank-specific, industry-specific and macroeconomic determinants of bank profitability. Journal of International Financial Markets Institutions and Money, 18(2), 121-136. 
Baele, L., De Jonghe, O., \& Vander Vennet, R. (2007). Does the stock market value bank diversification? Journal of Banking E' Finance, 31(7), 1999-2023. http://dx.doi. org/10.1016/j.jbankfin.2006.08.003.

Baltagi, B. H. (2013). Econometric analysis of panel data (5th ed.). Chichester, UK: John Wiley \& Sons Ltd.

Barajas, A., Steiner, R., \& Salazar, N. (1999). Interest spreads in banking in Colombia 1974-96. IMF Staff Papers, 46(2), 196-224.

Beck, T., Demirgüç-Kunt, A., \& Levine, R. (2000). A new database on the structure and development of the financial sector. World Bank Economic Review, 14(3), 597-605.

Ben Naceur, S., \& Goaied, M. (2008). The determinants of commercial bank interest margin and profitability: Evidence from Tunisia. Frontiers in Finance and Economics, 5(1), 106-130.

Ben Naceur, S., \& Omran, M. (2011). The effects of bank regulations, competition, and financial reforms on banks' performance. Emerging Markets Review, 12(1), 1-20. http://dx.doi.org/10.1016/j.ememar.2010.08.002.

Berger, A. N. (1995a). The profit-structure relationship in banking: Test of market-power and efficiency-structure hypotheses. Journal of Money, Credit, and Banking, 27(2), 404-431.

Berger, A. N. (1995b). The relationship between capital and earning in banking. Journal of Money, Credit, and Banking, 27(2), 432-456.

Berger, A. N., \& Bonaccorsi di Patti, E. (2006). Capital structure and firm performance: A new approach to testing agency theory and an application to the banking industry. Journal of Banking \&' Finance, 30(4), 1065-1102.

Berger, A. N., Hasan, I., \& Zhou, M. (2010). The effects of focus versus diversification on bank performance: Evidence from Chinese banks. Journal of Banking \& Finance, 34(7), 1417-1435. http://dx.doi.org/10.1016/j.jbankfin.2010.01.010.

de Blas, B., \& Russ, K. N. (2013). All banks great, small, and global: Loan pricing and foreign competition. International Review of Economics E` Finance, 26, 4-24. http://dx. doi.org/10.1016/j.iref.2012.08.005.

Blundell, R., \& Bond, S. (1998). Initial conditions and moment restrictions in dynamic panel data models. Journal of Econometrics, 87(1), 115-143.

Bond, S. (2002). Dynamic panel data models: A guide to micro data methods and practice. Portuguese Economic Journal, 1(2), 141-162.

Bourke, P. (1989). Concentration and other determinants of bank profitability in Europe, North America, and Australia. Journal of Banking E Finance, 13(1), 65-79.

Brock, P. L., \& Franken, H. (2003). Sobre los Determinantes de los Spreads Marginal y Promedio de las Tasas de Interés Bancarias: Chile 1994-2001. Economía Chilena, 6(3), 45-65.

Brock, P. L., \& Rojas Suárez, L. (2000). Understanding the behavior of bank spreads in Latin America. Journal of Development Economics, 63(1), 113-134. http://dx.doi. org/10.1016/s0304-3878(00)00102-4.

Brown, P., Beekes, W., \& Verhoeven, P. (2011). Corporate governance, accounting and finance: A review. Accounting and Finance, 51(1), 96-172. http://dx.doi.org/10. 1111/j.1467-629X.2010.00385.X.

Buser, S. A., Chen, A. H., \& Kane, E. J. (1981). Federal deposit insurance, regulatory policy, and optimal bank capital. The Journal of Finance, 36(1), 51-60. http://dx.doi. org/10.2307/2327463.

Carbó Valverde, S., \& Rodríguez Fernández, F. (2007). The determinants of bank margins in European banking. Journal of Banking E' Finance, 31(7), 2043-2063. http:// dx.doi.org/10.1016/j.jbankfin.2006.06.017.

Catão, L. (1998). Intermediation spreads in a dual currency economy-Argentina in the 1990s. IMF working paper, (90, 98). Washington, DC: International Monetary Fund.

Chaudhry, M., Chatrath, A., \& Kamath, R. (1995). Determinants of bank profitability. American Journal of Business, 10(1), 41-46.

Choi, I. (2001). Unit root tests for panel data. Journal of International Money and Finance, 20(2), 249-272. http://dx.doi.org/10.1016/S0261-5606(00)00048-6.

Chortareas, G. E., Garza-Garcia, J. G., \& Girardone, C. (2011). Banking sector performance in Latin America: Market power versus efficiency. Review of Development Economics, 15(2), 307-325. http://dx.doi.org/10.1111/j.1467-9361.2011.00610.x.

Cybo-Ottone, A., \& Murgia, M. (2000). Mergers and shareholder wealth in European banking. Journal of Banking E' Finance, 24(6), 831-859. http://dx.doi.org/10.1016/ S0378-4266(99)00109-0.

De la Torre, A., Ize, A., \& Schmukler, S. (2012). El Desarrollo Financiero en América Latina y el Caribe: El Camino por Delante (1st ed.). Washington, DC: The World Bank.

Demirgüç-Kunt, A., \& Huizinga, H. (1999). Determinants of commercial bank interest margins and profitability: Some international evidence. The World Bank Economic Review, 13(2), 379-408.

Demirgüç-Kunt, A., \& Levine, R. (2004). Financial structure and economic growth: A cross-country comparison of banks, markets, and development (1st. ed.). Massachusetts: Massachusetts Institute of Technology.

Demirgüç-Kunt, A., Laeven, L., \& Levine, R. (2004). Regulations, market structure, institutions, and the cost of financial intermediation. Journal of Money, Credit and Banking, 36(3), 593-622. http://dx.doi.org/10.2307/3838956.

DeYoung, R., \& Roland, K. P. (2001). Product mix and earnings volatility at commercial banks: Evidence from a degree of total leverage model. Journal of Financial Intermediation, 10(1), 54-84. http://dx.doi.org/10.1006/jfin.2000.0305.

Feldmann, H. (2012). Banking deregulation around the world, 1970s to 2000s: The impact on unemployment. International Review of Economics E Finance, $24,26-42$. http://dx.doi.org/10.1016/j.iref.2012.01.003.

Figlewski, S., Frydman, H., \& Liang, W. (2012). Modeling the effect of macroeconomic factors on corporate default and credit rating transitions. International Review of Economics E' Finance, 21(1), 87-105. http://dx.doi.org/10.1016/j.iref.2011.05.004.

Fungáčová, Z., \& Poghosyan, T. (2011). Determinants of bank interest margins in Russia: Does bank ownership matter? Economic Systems, 35(4), 481-495. http://dx. doi.org/10.1016/j.ecosys.2010.11.007.

Gelos, R. G. (2009). Banking spreads in Latin America. Economic Inquiry, 47(4), 796-814. http://dx.doi.org/10.1111/j.1465-7295.2008.00144.x.

Goddard, J., Molyneux, P., \& Wilson, J. O. S. (2004). The profitability of European banks: A cross-sectional and dynamic panel analysis. The Manchester School, 72(3), 363-381.

Hansen, L. P., Heaton, J., \& Yaron, A. (1996). Finite-sample properties of some alternative GMM estimators. Journal of Business E' Economic Statistics, 14(3), 262-280.

Hawtrey, K., \& Liang, H. (2008). Bank interest margins in OECD countries. The North American Journal of Economics and Finance, 19(3), 249-260. http://dx.doi.org/10. 1016/j.najef.2008.07.003.

Ho, T., \& Saunders, A. (1981). The determinants of Bank interest margins: Theory and empirical evidence. Journal of Financial and Quantitative Analysis, 16(4), 581-600.

Jara, M., López, F., \& López-de-Foronda, Ó. (2008). The contest to the control in European family firms: How other shareholders affect firm value. Corporate Governance: An International Review, 16(3), 146-159. http://dx.doi.org/10.1111/j.1467-8683.2008.00677.x.

Jensen, M. C. (1986). Agency cost of free cash flow, corporate finance, and takeovers. The American Economic Review, 72(6), 323-329.

Jensen, M. C., \& Meckling, W. (1976). Theory of the firm: Managerial behaviour, agency cost and ownership structure. Journal of Financial Economics, 3(4), 305-360.

Kim, J. -O., \& Mueller, C. W. (1978). Introduction to factor analysis: What it is and how to do it. Quantitative applications in the social sciences. Beverly Hills, CA: Sage University.

La Porta, R., Lopez-De-Silanes, F., \& Shleifer, A. (2006). What works in securities laws? The Journal of Finance, 61(1), 1-32. http://dx.doi.org/10.1111/j.1540-6261.2006. 00828.x.

Laeven, L., \& Levine, R. (2007). Is there a diversification discount in financial conglomerates? Journal of Financial Economics, 85(2), 331-367. http://dx.doi.org/10.1016/j. jfineco.2005.06.001.

Lepetit, L., Nys, E., Rous, P., \& Tarazi, A. (2008). Bank income structure and risk: An empirical analysis of European banks. Journal of Banking E Finance, 32(8), 1452-1467. http://dx.doi.org/10.1016/j.jbankfin.2007.12.002.

Lerner, E. M. (1981). Discussion: The determinants of bank interest margins: Theory and empirical evidence. Journal of Financial and Quantitative Analysis, 16(4), 601-602.

Lin, J. -R., Chung, H., Hsieh, M. -H., \& Wu, S. (2012). The determinants of interest margins and their effect on bank diversification: Evidence from Asian banks. Journal of Financial Stability, 8(2), 96-106. http://dx.doi.org/10.1016/j.jfs.2011.08.001.

Lind, J. T., \& Mehlum, H. (2010). With or without U? The appropriate test for a U-shaped relationship. Oxford Bulletin of Economics and Statistics, 72(1), 109-118. http:// dx.doi.org/10.1111/j.1468-0084.2009.00569.x. 
Maudos, J., \& Fernández de Guevara, J. (2004). Factors explaining the interest margin in the banking sectors of the European Union. Journal of Banking E' Finance, 28(9), 2259-2281. http://dx.doi.org/10.1016/j.jbankfin.2003.09.004.

Maudos, J., \& Solís, L. (2009). The determinants of net interest income in the Mexican banking system: An integrated model. Journal of Banking E' Finance, 33(10), 1920-1931. http://dx.doi.org/10.1016/j.jbankfin.2009.04.012.

Memmel, C., \& Raupach, P. (2010). How do banks adjust their capital ratios? Journal of Financial Intermediation, 19(4), 509-528.

Mercieca, S., Schaeck, K., \& Wolfe, S. (2007). Small European banks: Benefits from diversification? Journal of Banking E' Finance, 31(7), 1975-1998. http://dx.doi.org/10. 1016/j.jbankfin.2007.01.004.

Miller, S., \& Noulas, A. (1997). Portfolio mix and large-bank profitability in the USA. Applied Economics, 29(4), 505-512.

Molyneux, P., \& Thornton, J. (1992). Determinants of European bank profitability: A note. Journal of Banking E' Finance, 16, 1173-1178.

Molyneux, P., Remolona, E., \& Seth, R. (1998). Modeling foreign bank performance and lending behavior. Financial Markets, Institutions Ė Instruments, 7(4), 26-41. http://dx.doi.org/10.1111/1468-0416.00022.

Olson, D., \& Zoubi, T. A. (2011). Efficiency and bank profitability in MENA countries. Emerging Markets Review, 12(2), 94-110. http://dx.doi.org/10.1016/j.ememar.2011. 02.003.

Perry, P. (1992). Do banks gain or lose from inflation? Journal of Retail Banking, 14(2), 25-30.

Ramlall, I. (2009). Bank-specific, industry-specific and macroeconomic determinants of profitability in Taiwanese banking system: Under panel data estimation. International Research Journal of Finance and Economics, 34, 160-167.

Sanyal, P., \& Shankar, R. (2011). Ownership, competition, and bank productivity: An analysis of Indian banking in the post-reform period. International Review of Economics E' Finance, 20(2), 225-247. http://dx.doi.org/10.1016/j.iref.2010.05.002.

Saona, P. (2011). Determinants of the profitability of the US banking industry. International Journal of Business and Social Science, 2(22), 255-269.

Saunders, A., \& Schumacher, L. (2000). The determinants of bank interest rate margins: An international study. Journal of International Money and Finance, 19(6), 813-832. http://dx.doi.org/10.1016/s0261-5606(00)00033-4.

Short, B. (1979). The relation between commercial bank profit rates and banking concentration in Canada, Western Europe, and Japan. Journal of Banking \&' Finance, 3 , 209-219.

Singh, A., Belaisch, A., Collyns, C., De Masi, P., Krieger, R., Meredith, G., \& Rennhack, R. (2005). Stabilization and reform in Latin America: A macroeconomic perspective on the experience since the early 1990s. Occasional paper. Washington: IMF.

Sufian, F., \& Habibullah, M. (2009). Bank specific and macroeconomic determinants of bank profitability: Empirical evidence from the China banking sector. Frontiers of Economics in China, 4(2), 274-291. http://dx.doi.org/10.1007/s11459-009-0016-1.

Trujillo-Ponce, A. (2013). What determines the profitability of banks? Evidence from Spain. Accounting and Finance, 53(2), 561-586. http://dx.doi.org/10.1111/j.1467629X.2011.00466.x.

Valdez, S. (2007). An introduction to global financial markets (5th ed.). New York: Palgrave Macmillan.

Vallelado, E., \& Saona, P. (2011). An integrated model of capital structure to study the differences in the speed of adjustment to target long term debt ratio among developed countries. International Journal of Banking, Accounting and Finance, 3(4), 258-293.

Wall, L., \& Eisenbeis, R. (1984). Risk considerations in deregulating bank activities. Federal Reserve Bank of Atlanta Economic Review, 64(5), 6-19.

Warman, F. (2013). Integración del capital regulatorio en países Latinoamericanos y efectos de Basilea III. Boletín, LIX(3), 149-181.

Yeyati, E. L., \& Micco, A. (2007). Concentration and foreign penetration in Latin American banking sectors: Impact on competition and risk. Journal of Banking E' Finance, 31(6), 1633-1647. http://dx.doi.org/10.1016/j.jbankfin.2006.11.003. 